\title{
Article \\ Evaluation of Drought Tolerance of Some Wheat (Triticum aestivum L.) Genotypes through Phenology, Growth, and Physiological Indices
}

\author{
M. Kaium Chowdhury ${ }^{1}$, M. A. Hasan ${ }^{2}$, M. M. Bahadur ${ }^{2}$, Md. Rafiqul Islam ${ }^{3}$ (D) Md. Abdul Hakim ${ }^{4}$, \\ Muhammad Aamir Iqbal ${ }^{5}\left(\mathbb{D}\right.$, Talha Javed ${ }^{6,7}\left(\mathbb{D}\right.$, Ali Raza ${ }^{8}(\mathbb{D})$, Rubab Shabbir $^{6}(\mathbb{D})$, Sobhy Sorour ${ }^{9}$, \\ Norhan E. M. Elsanafawy ${ }^{9}$, Sultana Anwar ${ }^{10}$, Saud Alamri 11 ${ }^{\mathbb{D}}$, Ayman EL Sabagh $9,12, * \mathbb{D}$ and \\ Mohammad Sohidul Islam 13,*(D)
}

Citation: Chowdhury, M.K.; Hasan, M.A.; Bahadur, M.M.; Islam, M.R.; Hakim, M.A.; Iqbal, M.A.; Javed, T.; Raza, A.; Shabbir, R.; Sorour, S.; et al. Evaluation of Drought Tolerance of Some Wheat (Triticum aestivum L.) Genotypes through Phenology, Growth, and Physiological Indices. Agronomy 2021, 11, 1792.

https://doi.org/10.3390/agronomy 11091792

Academic Editor: Bujun Shi

Received: 18 August 2021

Accepted: 1 September 2021

Published: 7 September 2021

Publisher's Note: MDPI stays neutral with regard to jurisdictional claims in published maps and institutional affiliations.

Copyright: (c) 2021 by the authors. Licensee MDPI, Basel, Switzerland. This article is an open access article distributed under the terms and conditions of the Creative Commons Attribution (CC BY) license (https:/ / creativecommons.org/licenses/by/ $4.0 /)$.
1 Department of Agricultural Extension, Agricultural Training Institute, Gaibanda 5700, Bangladesh; kaium34bcs@gmail.com

2 Department of Crop Physiology \& Ecology, Hajee Mohammad Danesh Science and Technology University, Basherhat 5200, Bangladesh; mdabuhasan@yahoo.com (M.A.H.); mmbhstu@yahoo.com (M.M.B.)

3 Agronomy Division, Regional Agricultural Research Station, Bangladesh Agricultural Research Institute, Pabna 6600, Bangladesh; rafiq_bari2@yahoo.com

4 Department of Agricultural Chemistry, Hajee Mohammad Danesh Science and Technology University, Dinajpur 5200, Bangladesh; ahakimhstu.upm@gmail.com

5 Department of Agronomy, Faculty of Agriculture, University of Poonch Rawalakot, Rawalakot 12350, Pakistan; aamir1801@yahoo.com

6 College of Agriculture, Fujian Agriculture and Forestry University, Fuzhou 350002, China; mtahaj@fafu.edu.cn (T.J.); rubabshabbir28@gmail.com (R.S.)

7 Department of Agronomy, University of Agriculture, Faisalabad 38000, Pakistan

8 Fujian Provincial Key Laboratory of Crop Molecular and Cell Biology, Oil Crops Research Institute, Center of Legume Crop Genetics and Systems Biology/College of Agriculture, Fujian Agriculture and Forestry University (FAFU), Fuzhou 350002, China; alirazamughal143@gmail.com

9 Department of Agronomy, Faculty of Agriculture, Kafrelsheikh University, Kafr El-Shaikh 33516, Egypt; sobhysor@yahoo.com (S.S.); noraudy2020@gmail.com (N.E.M.E.)

10 Department of Agronomy, University of Florida, Gainesville, FL 32601, USA; sultana.anwar@yahoo.com

11 Department of Botany and Microbiology, College of Science, King Saud University, Riyadh 12211, Saudi Arabia; saualamri@ksu.edu.sa

12 Department of Field Crops, Faculty of Agriculture, Siirt University, Siirt 56100, Turkey

13 Department of Agronomy, Hajee Mohammad Danesh Science and Technology University, Dinajpur 5200, Bangladesh

* Correspondence: ayman.elsabagh@agr.kfs.edu.eg (A.E.S.); shahid_sohana@yahoo.com (M.S.I.) 
utilization in future wheat breeding programs aimed at developing potent drought-tolerant wheat genotypes to ensure food security on a sustainable basis.

Keywords: drought stress; wheat genotypes; phenological traits; physiological indices; drought tolerance

\section{Introduction}

Wheat (Triticum aestivum L.) of the family Gramineae is a popular grain crop of ancient origin. It constitutes one of the most important trade commodities as one-fifth of the world's wheat production is traded globally [1]. Wheat provides $21 \%$ of the food calories and $20 \%$ of the protein for more than 4.5 billion people in 94 countries, and as a global food crop, it contributes to food security for many countries. The annual production of wheat is estimated to be around 600 million Metric tons, which makes it the third largest crop in the world after corn (Zea mays L.) and rice (Oryza sativa L.) [2]. The yield is a complex trait that is strongly influenced by environmental stresses. The increasing yield potential has indisputable importance in solving the wheat food deficit, especially in Bangladesh. Under a changing climate, environmental stresses have emerged as the main threats to staple crop production. Recently, wheat production has been adversely influenced by the progressive global climatic changes and increasing shortage of water resources, coupled by the worsening of the ecoenvironment, which has compromised the nutritional security of the increasing population [3]. Among the environmental stresses, water scarcity or drought stress during the growing season and common stress in most arid and semi-arid areas severely reduces yield. In Bangladesh, it is generally grown under rain-fed conditions during the dry winter (November to April). The soil moisture retention, owing to monsoon rains, supports vegetative growth of wheat plants, however the reproductive stage is adversely affected with the depletion of the residual soil moisture [4]. Thus, drought stress (DS) incidence limits wheat productivity more severely than any other environmental stress [5].

DS adversely affects plant establishment and consequently growth and development. Cell enlargement and assimilates partitioning are hindered by DS [6]. Under extreme conditions, it may severely disturb several metabolic processes, resulting in diminished photosynthesis, impeded cell enlargement and division, and finally passed on the cells [6]. DS at the reproductive stage is more harmful to plant metabolic processes compared to the vegetative growth stage. This is because DS at anthesis markedly reduces photosynthesis, reproductive development, and finally grain yield [4,7]. However, this problem is feared to be further augmented due to climate change as global warming manifested through rising temperatures can potentially lead to a serious decline in soil moisture-holding capacity. Several management approaches have been proposed to combat DS, but there has been little work for screening out drought tolerant genotypes for cultivation in drought-prone areas. The selection of drought tolerant genotypes has been as the economically viable and biologically superior approach to boost wheat production in moisture deficient regions [8]. Genotypes should be tested for their drought tolerance based on phenology, morphology, physiology, and biochemical behavior at different growth stages from germination to maturity (tillering, jointing, booting, anthesis, grain filling, and physiological maturity stages) due to their variable responses to DS. Plants can tolerate by changing their physiological functions under drought stress, such as less reduction in water content [9], chlorophyll content [10], membrane stability [11], photosynthetic activity [12], dry matter production [11], higher accumulation of soluble sugars [13], proline content [10], amino acids [14], and enzymatic and non-enzymatic activities [15] to protect against oxidative stress. Therefore, drought-tolerant indices should be determined that can be used to identify DS tolerant and susceptible genotypes. The testing of crop genotypes for drought tolerance on their physiological response to DS may serve as the potent approach to screen out well development of new cultivars [16], but it involves a deeper understanding of the yield determining process [17]. In addition, evaluating the physiological 
changes occurring under DS may lead to genetic improvement of drought tolerant genotype. It remains a vital challenge to develop drought tolerant genotypes while maintaining higher yields, while selection of drought tolerant genotypes to serve as donor parents prerequisites any future breeding program. However, immense research and knowledge gaps exist pertaining to wheat genotypes evaluation on tolerance indices, phenology, and physiological traits under DS. Thus, we hypothesized that wheat genotypes might respond differently in terms of phonological and physiological traits to DS owing to varying genetic potential and screening of most superior genotypes that can boost wheat production under changing climate. The present field experiment was aimed to evaluate physiological and phenological traits in wheat genotypes under DS conditions for sorting out the most drought tolerant genotype for general adoption in the region.

\section{Material and Methods}

\subsection{Location and Duration}

The experiment site used was the research farm of the Department of Crop Physiology and Ecology (CPE), Hajee Mohammad Danesh Science and Technology University (HSTU), Dinajpur, Bangladesh $\left(25^{\circ} 39^{\prime} \mathrm{N}\right.$ latitude and $88^{\circ} 41^{\prime} \mathrm{E}$ longitude with a $37.58 \mathrm{~m}$ altitude) [18] The experimental site falls in the agro-ecological zone (AEZ-1) of Old Himalayan Piedmont Plain. The experiment was executed during the winter season from November to April 2018.

\subsection{Soil}

The experimental field was a medium-high land belonging to the non-calcarious dark gray floodplain soil. The soil is sandy loam under the Order Inceptisol and belongs to the Ranishankail series. It is classified as Non-Calcareous Brown Floodplain Soil with Piedmont alluvium parent material [18]. The soil is characterized as acidic in nature, having a field capacity of $25.8 \%$, permanent wilting point at $12.0 \%$, and bulk density of $0.86-1.07 \mathrm{~g} \mathrm{~cm}^{-3}$. The organic matter content of the soil is low $(0.69)$. The physical and chemical properties of the experimental soil up to the depth of $15 \mathrm{~cm}$ were studied to know the initial status (Tables 1 and 2) before conducting the experiment.

Table 1. General characteristics of soil of the experimental site.

\begin{tabular}{cc}
\hline General Characters & Description \\
\hline Location & Crop Physiology and Ecology, HSTU, Dinajpur \\
AEZ & Old Himalayan Piedmont Plain (AEZ-1) \\
General Soil type & Non-Calcareous Brown Floodplain Soil \\
Parent material & Piedmont alluvium \\
Soil series & Ranishankail \\
Drainage & Moderately well-drained \\
Flood level & Above flood level \\
Topography & High land \\
\hline
\end{tabular}

Table 2. Initial soil physical and chemical properties of experimental fields and their interpretation according to fertilizer recommendation guide [19].

\begin{tabular}{ccccc}
\hline Soil Characters & Analytical Value & Critical Level & $\begin{array}{c}\text { Soil Test Values } \\
\text { Interpretation }\end{array}$ & $\begin{array}{c}\text { Range of Value Used within } \\
\text { the Interpretation Class }\end{array}$ \\
\hline & \multicolumn{3}{c}{ Physical properties } \\
\hline Sand (\%) & 60.00 & - & - & - \\
Silt (\%) & 27.00 & - & - & - \\
Clay (\%) & 13.00 & - & - & - \\
Textural class & Sandy loam & - & - & - \\
Bulk density(g/cc) & $0.86-1.07$ & - & - & - \\
Field capacity (\%) & 25.8 & - & - & - \\
Permanent wilting point & 12.0 & - & \\
\hline
\end{tabular}


Table 2. Cont.

\begin{tabular}{|c|c|c|c|c|}
\hline Soil Characters & Analytical Value & Critical Level & $\begin{array}{l}\text { Soil Test Values } \\
\text { Interpretation }\end{array}$ & $\begin{array}{l}\text { Range of Value Used within } \\
\text { the Interpretation Class }\end{array}$ \\
\hline \multicolumn{5}{|c|}{ Chemical properties } \\
\hline Soil pH (1:1.25, Soil: $\left.\mathrm{H}_{2} \mathrm{O}\right)$ & $5.40-5.50$ & - & - & - \\
\hline $\begin{array}{c}\text { Organic matter }(\%) \text { (Wet oxidation } \\
\text { method) }\end{array}$ & 0.69 & - & Low & - \\
\hline $\begin{array}{l}\mathrm{CEC} \text { (meq/100g soil) }\left(\mathrm{BaCl}_{2-}^{-}\right. \\
\text {compulsive exchange method) }\end{array}$ & 5.60 & - & Low & - \\
\hline $\begin{array}{c}\text { Total nitrogen (\%) (Micro-Kjeldahl } \\
\text { method) }\end{array}$ & 0.07 & 0.12 & Low & $\leq 0.09$ \\
\hline $\begin{array}{c}\text { Available phosphorus }\left(\mu \mathrm{g} \mathrm{g}^{-1}\right) \\
\text { (Molybdate blue ascorbic acid } \\
\text { method) }\end{array}$ & 16.75 & 10.00 & Medium & $7.51-15.0$ \\
\hline $\begin{array}{l}\text { Exchangeable potassium (meq100 } \\
\qquad \mathrm{g}^{-1} \text { soil) } \\
\text { (Flame photometer method) }\end{array}$ & 0.17 & 0.12 & Low & $0.18-0.27$ \\
\hline $\begin{array}{c}\text { Available sulphur }\left(\mu \mathrm{g} \mathrm{g}^{-1}\right) \\
\text { (Turbidity method using } \mathrm{BaCl}_{2} \text { ) }\end{array}$ & 17.53 & 10.00 & Medium & $15.10-22.50$ \\
\hline $\begin{array}{l}\text { Available boron }\left(\mu \mathrm{g} \mathrm{g}^{-1}\right) \text { (Calcium } \\
\text { chloride extraction method) }\end{array}$ & 0.15 & 0.20 & Very low & $\leq 0.15$ \\
\hline $\begin{array}{c}\text { Available zinc }\left(\mu \mathrm{g} \mathrm{g}^{-1}\right) \text { (Atomic } \\
\text { Absorption Spectrophotometer } \\
\text { method) }\end{array}$ & 0.88 & 0.60 & Low & $0.45-0.90$ \\
\hline
\end{tabular}

N.B.: Analysis of initial soil samples was performed from Soil Resources and Development Institute (SRDI), Dinajpur, Bangladesh.

\subsection{Climate}

The experimental site is situated in the sub-tropical region receiving a major portion of rainfall during the months from May to September and scant rainfall during the rest of the year. In this study, the weather data, including temperature, rainfall, and relative humidity (RH) during November to April of the HSTU campus were recorded at the HSTU Meteorological Station, HSTU, Dinajpur (Table 3). The average maximum and minimum temperature, $\mathrm{RH}$, and rainfall were 25.4 and $15.22^{\circ} \mathrm{C}, 82.0 \%$, and $8.00 \mathrm{~mm}$, respectively. Rainfall occurred extremely at 55-61 DAS, i.e., grain filling stage.

Table 3. Weather data during the growing period of wheat at the HSTU campus, Dinajpur.

\begin{tabular}{ccccc}
\hline \multirow{2}{*}{ Months } & \multirow{2}{*}{ Relative Humidity (\%) } & \multicolumn{2}{c}{ Temperature } & \multirow{2}{*}{ Total Rainfall (mm) } \\
\cline { 3 - 5 } & & Minimum $\left({ }^{\circ} \mathbf{C}\right)$ & Maximum $\left({ }^{\circ} \mathbf{C}\right)$ & 0.0 \\
November & 87 & 15.9 & 25.6 & 0.0 \\
December & 85 & 10.9 & 21.9 & 4.0 \\
January & 72 & 9.6 & 25.8 & 8.0 \\
February & 78 & 14.7 & 29.7 & 3.0 \\
March & 81 & 17.5 & 30.9 & 33.0 \\
April & 89 & 22.7 & & \\
\hline
\end{tabular}

Source: Meteorological Station, HSTU, Dinajpur.

\subsection{Experimental Design and Treatments}

The experiment was conducted in a split plot design with three replications. The unit plot size was $4.0 \mathrm{~m} \times 2.5 \mathrm{~m}$. The spacing between plots and blocks were 0.75 and $1.0 \mathrm{~m}$, respectively. The main plots contained well-watered (WW) condition (three irrigation at 20, 50, 70 days after sowing-DAS) and drought stress condition (no irrigation), while sub-plots had four wheat genotypes viz., (i) BARI Gom 26, (ii) BAW 1158, (iii) BAW 1167, and (iv) BAW 1169. Wheat genotypes and their pedigree history are presented in Table 4. 
Table 4. Wheat genotypes and their pedigree/selection history used for the present study.

\begin{tabular}{ccc}
\hline Sr. No. & Genotypes & Pedigree/Selection History \\
\hline 1 & BARI Gom 26 (BAW 1064) & Variety, ICTAL123/3/RAWAL87//VEE/HD2285 \\
2 & BAW 1158 & BD(JOY) 86-0JO-3JE-010JE-010JE-HRDI-RC5DI \\
3 & BAW 1167 $968 /$ SHATABDI \\
4 & BAW 1169 & BL 3877 = KAUZ/STAR/CMH 81.749//BL 2224 \\
\hline
\end{tabular}

BARI: Bangladesh Agricultural Research Institute; BAW: Bangladesh Wheat, SHATABDI: Wheat variety.

\subsection{Experimentation}

A power tiller was employed for plowing the experimental field, which was leveled by harrowing and laddering carefully. Afterward, weeds and previous crop leftovers were manually removed to demark main plots, sub-plots, and blocks. Fertilizers including $\mathrm{N}, \mathrm{P}, \mathrm{K}, \mathrm{S}, \mathrm{Zn}$, and B were applied at the rate of 90-85-66-20-2-0.5 $\mathrm{kg} \mathrm{ha}^{-1}$, respectively, in the form of urea (N: $46 \%$ ), triple supper phosphate (TSP: $50 \% \mathrm{P}_{2} \mathrm{O}_{5}$ ), murate of potash (MP: $60 \% \mathrm{~K}_{2} \mathrm{O}$ ), gypsum (S: $18 \%$ ) and boric acid (B: $\left.17 \%\right)$, respectively. Full doses of all fertilizers except $\mathrm{N}$ (one-third) were incorporated thoroughly into the soil as basal dose. The remaining $\mathrm{N}$ was further split into two doses for application at 20 and 50 days after sowing (DAS). Wheat seeds of all genotypes were sown using $120 \mathrm{~kg} \mathrm{ha}^{-1}$ seed rate in $20 \mathrm{~cm}$ apart rows. A shallow irrigation was applied in all plots just after sowing for promoting uniform germination and seedling establishment. Plots were irrigated three times (at 21, 50, and 70 DAS) for WW treatment, and the remaining plots were not irrigated throughout the growing period and protected from rainfall by using rainout shelter (transparent polythene sheet) to maintain DS condition. After sowing, care was taken against birds up to 15 days. The crop was kept weed-free, and to control diseases, Tilt $250 \mathrm{EC}$ was sprayed regularly at 15 days intervals after 30 days of sowing.

\subsection{Data Collection}

\subsubsection{Phenological Indices}

During the crop cycle, the dates of booting, heading, anthesis, and physiological maturity were recorded using the scale proposed by [20].

\subsubsection{Physiological Indices \\ Relative Water Content (RWC)}

The RWC in the flag leaves was determined at 12 days after anthesis (DAA). The leaf lamina, after collecting from the field was sealed immediately in plastic bags and quickly transferred to the laboratory. Fresh weight (FW) was taken immediately, and the leaves were placed in distilled water in test tubes. Turgid weight (TW) was obtained after soaking leaves in water for about $24 \mathrm{~h}$ at room temperature. Dry weight (DW) was obtained after oven drying the leaf samples at $80^{\circ} \mathrm{C}$ for $72 \mathrm{~h}$. The values of the fresh, turgid, and dry weights of the flag leaves were used to calculate the RWC according to the following formulae used by [21].

$$
\text { RWC }(\%)=\frac{\text { Fresh weight }- \text { Dry weight }}{\text { Turgid weight }- \text { Dry weight }} \times 100 \%
$$

\section{Chlorophyll Estimation}

At 8 and 24 DAA, the chlorophyll content of the flag leaf was determined by the protocol of [22]. The leaf samples of $1 \mathrm{mg}$ were taken from different flag leaf positions. The samples were grinded with the help of mortar and pestle and subsequently chlorophyll was extracted using aqueous acetone $(80 \%)$. Later, the suspension was placed in centrifuge tubes, and centrifuged (CENTRIFUGE, DSC-158T 220, RPM 3200, AMPS 2; Made in Taiwan R.O.C.) for $3 \mathrm{~min}$. Then, a clear green solution was extracted from the colorless residue. The solution's optical density was measured using $80 \%$ acetone with the help 
of spectrophotometer at 645 and $663 \mathrm{~nm}$. Leaf's total chlorophyll was determined by employing the following formulae [22]:

$$
\begin{aligned}
& \text { Total chlorophyll }\left(\mathrm{mg} \mathrm{g}^{-1} \mathrm{FW}\right)=[20.2(\mathrm{D} 645+8.02(\mathrm{D} 663)] \times[\mathrm{v} /(1000 \times \mathrm{w})] \\
& \text { Where, } \mathrm{V}=\text { final volume of filtrated extract; } \\
& \mathrm{W} \text { = weight of fresh leaf; } \\
& \text { D645 = absorbance at } 645 \mathrm{~nm} \text { wavelength; } \\
& \text { D663 }=\text { absorbance at } 663 \mathrm{~nm} \text { wavelength. }
\end{aligned}
$$

\section{Canopy Temperature Depression (CTD)}

The difference between ambient air temperature and canopy temperature in degree centigrade is known as CTD. The handheld infra-red thermometer (Model: Crop TRAC item no. 2955L-Spectrum Technologies, Inc. Beijing-10000, China) was used to measure this trait from approximately $50 \mathrm{~cm}$ above the canopy at a $30^{\circ}$ angle from the horizon. The CTD was recorded at 16 DAA under bright sunlight and negligible wind conditions by using the following formula [23].

$$
\mathrm{CTD}\left({ }^{\circ} \mathrm{C}\right)=\text { Ambient Temperature }(\mathrm{Ta})-\text { Canopy Temperature }(\mathrm{Tc})
$$

\section{Estimation of Proline}

Proline content of flag leaf and kernel in all wheat genotypes were estimated at 16 DAA following the standard method [24]. Flag leaves and spikes from each replication of each genotype were collected and immediately kept in the ice-bag and brought to the Laboratory. The kernels from the spike were separated, and $0.5 \mathrm{~g}$ of fresh weight of both flag leaf and kernels were taken for proline estimation. At first, ninhydrin reagent was prepared and utilized for proline estimation within two hours of preparation. To prepare ninhydrin reagent, $30 \mathrm{~mL}$ glacial acetic acid and $20 \mathrm{~mL} 6 \mathrm{M}$ orthophosphoric acid was mixed with $1.25 \mathrm{~g}$ of ninhydrin. It was subsequently heated and stirred gently to dissolve, but the temperature was not allowed to exceed $70{ }^{\circ} \mathrm{C}$. Proline standards $(0,2,4,6,8,10,12,14$, 16,18 , and $20 \mu \mathrm{g} / \mathrm{mL}$ ) were prepared with distilled water. Using mortar and pestle, $0.5 \mathrm{~g}$ fresh sample was grinded and thoroughly homogenized in 3\% sulpho salicylic acid (10 mL) until digestion of plant material. The filtration of homogenate was performed using filter paper (Whatman No. 2). Then, in a Pyrex test tube, filtrate $(2 \mathrm{~mL})$ and standard proline solution were reacted with ninhydrin reagent $(2 \mathrm{~mL})$ and glacial acetic acid $(2 \mathrm{~mL})$. These were subsequently boiled in water bath that was covered with aluminum foil to hamper evaporation for $1 \mathrm{~h}$ at $100^{\circ} \mathrm{C}$. Subsequently, cooling of mixture in ice bath was performed and toluene $(4 \mathrm{~mL})$ was added in each tube with the help of a dispenser. The shaking of each tube was for 15-20 s with the help of an electrical shaker was performed to allow the layers to separate. The spectrophotometer (SPECTRO UV-VIS RS Spectrophotometer, Labo Med, Inc.) at $520 \mathrm{~nm}$, having pure toluene as a blank, was used for absorbance of the layer. From a standard curve, proline content was estimated on a fresh weight basis by following the below equation:

Proline $(\mu$ moles $/ \mathrm{g}$ of fresh plant materials $)=\{(\mu \mathrm{g}$ proline $/ \mathrm{mL} \times \mathrm{mL}$ toluene $) / 115.5 \mu \mathrm{g} / \mu \mathrm{moles}\} /(\mathrm{g}$ sample $/ 5)$

\section{Measurement of Photo-Assimilates}

To quantify spike dry matter (SDM) accumulation pattern, three spikes from main shoot were cut at anthesis stage with 4 days interval under normal and water deficit conditions. The samples were kept in an oven at $80^{\circ} \mathrm{C}$ for $72 \mathrm{~h}$ and subsequently weighed using an analytical balance (Model EK $300 \mathrm{i}$ ). The samples were collected from an area of $1.5 \mathrm{~m} \times 1 \mathrm{~m}$ from the center of each plot by cutting the plant at ground level at the harvesting stage. Ten plant samples from each treatment were taken, and the weight of spikelets spike ${ }^{-1}$ was measured. The samples were dried under the sun, threshed and 
cleaned manually and grain weight was taken after drying in the sun. Grain yield was expressed in $\mathrm{t} \mathrm{ha}^{-1}$ with moisture adjusted at $12 \%$.

\subsection{Statistical Analysis}

The recorded data were subjected to statistical analyses by partitioning the total variance using computer run statistical program "MSTAT-C" (Statistical software packages developed by the Crop and Soil Sciences Department, Michigan State University, East Lansing, MI, USA) [25]. The significance among treatment means were compared by employing Duncun's Multiple Range Test (DMRT) at $p \leq 5 \%$ level of probability.

\section{Results and Discussion}

\subsection{Phenological Characteristics}

3.1.1. Days to Booting (DB)

The DS significantly influenced the DB in the present study by hastening the booting stage for three days earlier (Table 5). The time required to attain the booting stage varied significantly among the genotypes. In DS, the genotype BAW 1169 required the maximum days ( $55.33 \mathrm{~d}$ ) to attain a booting stage that was statistically similar to BAW 1158 (54.65 d). Conversely, BAW 1167 required the minimum days (46.42 d) to attain the booting stage, followed by BARI Gom 26 (50.23 d). The results are certified by Maman et al. [26], who reported earlier that water deficit stress accelerates the booting stage. This may be due to DS slowing down photosynthesis and translocation of photosynthates (demonstrated by SDM), and this affects overall plant development, which is reflected by the overall shortening of the DB. DS may shorten the DB and accelerate the senescence of wheat genotypes [27]. The plants of BAW 1169 genotype strive to complete their growth period as early as possible to cope with drought stress conditions.

Table 5. Effect of DS on days required to attain different phenophases in different wheat genotypes.

\begin{tabular}{|c|c|c|c|c|c|}
\hline \multicolumn{2}{|c|}{ Treatment } & Days to Booting & Days to Heading & Days to Anthesis & Days to Physiological Maturity \\
\hline \multicolumn{6}{|c|}{ Water levels } \\
\hline \multirow{4}{*}{\multicolumn{2}{|c|}{$\begin{array}{c}\text { Well watered } \\
\text { Water stress } \\
\text { CV }(\%)\end{array}$}} & $51.21 \mathrm{a}$ & $63.54 \mathrm{a}$ & $75.22 \mathrm{a}$ & $107.78 \mathrm{a}$ \\
\hline & & $49.11 \mathrm{a}$ & $59.23 \mathrm{~b}$ & $70.54 \mathrm{~b}$ & $101.41 \mathrm{~b}$ \\
\hline & & 1.41 & 1.52 & 1.77 & 1.57 \\
\hline & & & Genotypes & & \\
\hline \multicolumn{2}{|c|}{ BARI Gom 26} & $50.23 \mathrm{~b}$ & $59.85 \mathrm{~b}$ & $71.24 \mathrm{~b}$ & $103.58 \mathrm{~b}$ \\
\hline \multicolumn{2}{|c|}{ BAW 1158} & $54.65 \mathrm{a}$ & $63.56 \mathrm{a}$ & $75.63 \mathrm{a}$ & $105.11 \mathrm{a}$ \\
\hline \multicolumn{2}{|c|}{ BAW 1167} & $46.42 \mathrm{~b}$ & $58.96 \mathrm{~b}$ & $68.42 \mathrm{~b}$ & $102.62 \mathrm{~b}$ \\
\hline \multicolumn{2}{|c|}{ BAW 1169} & $55.33 \mathrm{a}$ & $66.23 \mathrm{a}$ & $75.63 \mathrm{a}$ & $106.21 \mathrm{a}$ \\
\hline \multicolumn{2}{|c|}{ CV $(\%)$} & 1.24 & 2.00 & 0.75 & 0.66 \\
\hline \multicolumn{6}{|c|}{ Genotypes $\times$ Water levels } \\
\hline \multirow{2}{*}{ BARI Gom 26} & WW & $49.72 \mathrm{~b}$ & $60.23 \mathrm{~b}$ & $75.22 \mathrm{a}$ & $106.62 \mathrm{a}$ \\
\hline & DS & 46.85 c & $56.63 \mathrm{c}$ & $70.06 \mathrm{~b}$ & $99.15 \mathrm{c}$ \\
\hline \multirow{2}{*}{ BAW 1158} & WW & $56.61 \mathrm{a}$ & $65.43 \mathrm{a}$ & 74.23 a & 107.98 a \\
\hline & DS & $54.96 \mathrm{ab}$ & $63.85 a$ & $72.40 \mathrm{ab}$ & $104.16 \mathrm{ab}$ \\
\hline \multirow{2}{*}{ BAW 1167} & WW & $48.96 \mathrm{~b}$ & $59.11 b$ & $72.23 \mathrm{ab}$ & $104.25 \mathrm{~b}$ \\
\hline & DS & $45.65 \mathrm{c}$ & $54.63 c$ & $66.30 \mathrm{c}$ & $94.04 \mathrm{~d}$ \\
\hline \multirow{2}{*}{ BAW 1169} & WW & $57.23 \mathrm{a}$ & $67.11 \mathrm{a}$ & $75.84 \mathrm{a}$ & $108.83 \mathrm{a}$ \\
\hline & DS & $56.42 \mathrm{a}$ & $65.81 \mathrm{a}$ & $74.16 \mathrm{a}$ & 105.77 a \\
\hline \multicolumn{2}{|c|}{ CV (\%) } & 1.24 & 2.00 & 0.75 & 0.66 \\
\hline
\end{tabular}

In a column, values having same letter(s) within main effects and interaction effect did not differ significantly by DMRT at $p \leq 5 \%$ level; $\mathrm{CV}$ : coefficient of variation.

\subsubsection{Days to Heading (DH)}

There was a significant difference in $\mathrm{DH}$ for the genotypes under water treatments. DS reduced the days required for heading from 63.54 to $59.23 \mathrm{~d}$ (Table 5). DS has been shown to hasten the growth stage and causes a significant reduction in the number of 
DH [11]. Remarkable variations regarding the DH were also observed among the genotypes. For characterizing genotypes, recording and analysis of DH is a useful tool. DS generally decreased the days required to initiate heading or flowering due to the early start of the reproductive stage [28]. However, the genotype BAW 1169 required the maximum DH (66.23 d), which was statistically similar to BAW 1158 (65 d), while the minimum days required for heading $(58.63 \mathrm{~d})$ were recorded in BAW 1167 (58.96 d) followed by BARI Gom 26 genotypes $(60.05 \mathrm{~d})$. In DS conditions, the earliest heading $(54.63 \mathrm{~d})$ was recorded in BAW 1167 followed by BARI Gom 26 (56.63 d), but the maximum days (65.81 d) were recorded in BAW 1169 followed by BAW 1158 (63.85 d). No significant variation between WW and DS regarding the DH in both BAW 1169 and BAW 1158 genotypes. Drought sensitive genotypes tend to switch to heading earlier under DS, and therefore have a shortened life cycle, whereas drought-tolerant varieties showed non-significant difference in the heading time [29], and by considering this observation, BAW 1169 and BAW 1158 were considered as DS tolerant genotypes. Early heading has also been considered as an indicator of increased tolerance to drought in semi-arid locations [30], a major drought escaping mechanism, particularly in terminal drought stresses in durum and bread wheat [31], and yield improvement [32]. In rain-fed conditions, earlier flowering of wheat tends to provide balanced moisture consumption at pre- and post-anthesis stages, which promote grain filling. Wheat varieties having earlier flowering were matured in lesser time and thus partially escaped from drought; thus, such varieties tend to complete their life cycle before dehydration caused by high temperatures. Our results are as well in agreement with those of previous researchers [27,33], where they reported that DS significantly reduced the $\mathrm{DH}$ of bread and durum wheat genotypes. Nevertheless, there is a contradictive finding, according to which no remarkable variation on the DH of bread wheat varieties due to DS was observed in another study [34]. Hence, plants acclimatization with the soil moisture availability by matching the growth duration is vital for producing grain yield as per varietal potential [35]. The phenological development stages of plants are successfully matched with the periods of soil moisture availability, i.e., crop growth season is shortened to escape the drought stress [6]. Optimum water supply at booting and flowering, heading, and milking stages enhanced the crop yield [36]. Therefore, the selection of early maturing genotypes has also been believed to be an effective strategy for minimizing the losses of yield from DS, and less distressed genotypes to DH are considered as tolerant.

\subsubsection{Days to Anthesis (DA)}

Days to anthesis significantly differed between the irrigated and non-irrigated conditions ranging from 70.54 to $75.22 \mathrm{~d}$. Wheat genotypes pronouncedly effected the number of days required to attain anthesis (Table 5). The maximum days (75.65 and $75.63 \mathrm{~d}$ ) were required to attain the anthesis stage in BAW 1169 and BAW 1158, respectively. On the contrary, the minimum days were required in BAW 1167 (68.42 d). A significant interaction was found between water levels and wheat genotypes on the number of DA. However, in DS conditions, the maximum number of DA (74.16 d) was recorded in BAW 1169, which differed significantly with other genotypes, and the minimum DA $(66.30 \mathrm{~d})$ was recorded in BAW 1167 among all genotypes. No remarkable variation on DA of BAW 1158 and BAW 1169 due to DS was observed in this study. Pre-anthesis period is highly sensitive for obtaining grain yield attributes such as the number of grain per spike [37], while grains weight depends largely on post-anthesis period. The reduced grain-filling time allows terminal stress avoidance, while in comparison, longer duration triggers stem reserves utilization for grain filling under stress. The improvement of cultivar yield under DS resulted from a more extended grain filling duration [38]. Previous findings [27,33] concerning the number of DA have shown that DS significantly reduced the DA of wheat genotypes, as observed in the present study. Wheat genotypes escape DS by earlier heading and maturing, which indicates as the characteristics of drought-tolerant genotypes [30]. In addition, DS enhances senescence by accelerating chlorophyll degradation, leading to a decrease in leaf area and photosynthesis [39]. These observations corroborate our findings pertaining to 
reduced SDM. There is evidence that stay-green phenotypes with delayed leaf senescence under drought conditions can improve their tolerance performance [40]. Although, the grain-filling rate is determined mostly by genetic factors, and the grain-filling duration is controlled by environmental factors [41]. The DS accelerated the anthesis stage of all genotypes, but tolerant genotypes delayed anthesis almost similar to normal plants in this study. Similarly, findings have been earlier reported by various researchers [42,43], therefore, based on longer DA of BAW 1169 and BAW 1158, these might be declared drought tolerant genotypes.

\subsubsection{Days to Physiological Maturity (DPM)}

The phenological development duration of wheat genotypes constitutes one of the most pertinent factors for grain yield estimation under any specific environment [44]. The growth period duration interacts with phenological development, leading to higher grain yield owing to balanced consumption of resources, especially moisture, and by reducing the adverse effects of environmental stresses through shortening of growth periods [45]. Days required to physiological maturity showed a significant relationship within the growing condition, wheat genotypes, and their interaction (Table 5). Plants physiologically matured $6.37 \mathrm{~d}$ earlier owing to DS over control plants. BAW 1169, BAW 1158, and BARI Gom 26 required the maximum days (106.21, 105.11, and $103.58 \mathrm{~d}$, respectively) to attain physiological maturity, whereas BAW 1167 required the minimum days (102.12 d). In DS, the highest DPM was obtained in BAW 1169 (105.77 d), followed by BAW 1158 (104.16 d), and the minimum was recorded in BAW 1167 (94.04 d). Wheat genotypes escaped DS by finishing their life cycle in advance and matured earlier, which may be due to the genetic divergence. DS-induced reductions of DPM in wheat genotypes have been reported in various research $[39,46]$, presumably due to the senescence of canopy earlier. The decrease in maturity days under DS might be controlled by the lowering of nutrients in the plants (data not shown), which decreased chlorophyll in leaves (see Section 3.2.2 Chlorophyll Content) due to the lack of nitrogen needed for the assimilation. The loss of the chloroplast integrity in the leaf causes the early senescence in DS that ultimately leads plants to mature early. In the present study, DS decelerated the physiological maturity stage of BAW 1169 and BAW 1158 as affirmed tolerant genotypes, which were supported by several researchers $[42,43,47]$, with less reduction of DPM in response to DS.

\subsection{Physiological Indices}

\subsubsection{Relative Water Content (RWC)}

RWC is an important characteristic that measures water status in plants reflecting the ongoing metabolic activities in tissues and that may be used as a reliable indicator of drought tolerance. The RWC in flag leaf at 12 DAA was profoundly affected by DS in all wheat genotypes (Table 6). However, the RWC was decreased under DS, but all the genotypes recorded varying levels of reduction. As compared to control, the highest reduction $(8.42 \%)$ due to DS was recorded in BAW 1167, then BARI Gom $26(7.70 \%)$, and the lowest (2.59\%) was in BAW 1169, and slightly higher in BAW 1158 (3.47\%). The results indicated that genotypes BAW 1169 and BAW 1158 maintained a greater amount of water in the leaves under DS than the other two genotypes. A less reduction of RWC in response to DS has been noted for drought-tolerant genotypes [48]. The results of our study were in close agreement with the findings obtained by [49], who reported that wheat plants subjected to DS significantly reduced the RWC. Reduction of RWC in leaves might be associated with the loss of water as well as the variations of water uptake among the genotypes. Increased leaf water retention (LWR) through less reduction of RWC due to DS could be attributed to rolling of leaves, which results in serious decline of exposed surface area, and thus might be used as an indicator for determining the drought tolerance potential of crop plants [50]. Genotypes that established high LWR under DS tend to have significantly higher potential for preserving water balance in leaves, which reflects their DS tolerance. As DS leads to scarcity of water in the root zone, plants slow down water loss by 
closing stomata for surviving under DS. Therefore, RWC and leaf rolling hold perspectives for utilization in breeding programs aimed at improving the drought tolerance and boosting genetic potential for higher grain yields [51]. In addition, RWC shows strong positive correlations with water use efficiency (WUE), whereas the transpiration rate expresses negative correlation with WUE under drought stress [52]. RWC in leaves is responsive to DS and correlates with drought tolerance [53], and is a better indicator of DS than any indices of plants [54]. Genotypes may have the ability to absorb water from the soil or the ability of stomata to reduce the loss of water under DS. Wheat plants under DS conditions decreased dry matter production and RWC [55], showing that RWC and photosynthetic rates were positively correlated [56], and high RWC (higher osmotic regulation and lesser tissues cell walls elasticity) indicates DS tolerance [57]. Under DS, reduction of RWC indicates turgor pressure decline in plant cells, which leads to growth retardation [58]. In response to DS, roots generate chemical signals, which leads to stomatal closure and reduction in stomatal conductance [59]. Variation of RWC among the genotypes may be owing to diverse genetic potential for absorbing water from the rhizosphere and extending the depth of roots to exploit lower soil horizons for moisture extraction [60]. Plants strive to alleviate the damaging effects of stress by altering their metabolism to cope with stress. However, the genotypes with reduced leaf water loss due to DS are believed to be more drought tolerant [34], and RWC may be used as a useful indicator in order to screen out wheat genotypes having superior drought tolerance. As far as RWC is concerned, the genotype BAW 1169 followed by BAW 1158 may be suggested as drought-tolerant, owing to a minimum relative reduction of RWC.

Table 6. Effect of DS on the relative water content in the flag leaf of different wheat genotypes at 12 DAA.

\begin{tabular}{|c|c|c|c|}
\hline \multirow{2}{*}{ Genotypes } & \multirow{2}{*}{ Water Levels } & \multicolumn{2}{|c|}{ Relative Water Content (RWC) } \\
\hline & & $\%$ & $\%$ Change Over Normal \\
\hline \multirow{2}{*}{ BARI Gom 26} & Well watered & $87.96 \mathrm{~b}$ & - \\
\hline & Water stress & $81.19 \mathrm{~d}$ & -7.70 \\
\hline \multirow{2}{*}{ BAW 1158} & Well watered & $88.17 \mathrm{ab}$ & - \\
\hline & Water stress & $85.11 \mathrm{c}$ & -3.47 \\
\hline \multirow{2}{*}{ BAW 1167} & Well watered & $91.41 \mathrm{a}$ & - \\
\hline & Water stress & $83.71 \mathrm{~cd}$ & -8.42 \\
\hline \multirow{2}{*}{ BAW 1169} & Well watered & $89.56 \mathrm{a}$ & - \\
\hline & Water stress & $87.24 \mathrm{~b}$ & -2.59 \\
\hline \multicolumn{2}{|c|}{ Level of significance } & * & \\
\hline \multicolumn{2}{|c|}{ CV $(\%)$} & 1.28 & \\
\hline
\end{tabular}

In a column, values having same letter(s) did not differ significantly by DMRT at $p \leq 5 \%$ level; * indicates significant at $5 \%$ level of probability.

\subsubsection{Chlorophyll Content}

In order to screen out drought-tolerant wheat genotypes, Chl content has been assessed successfully by many researchers [61]. Drought tolerant genotypes maintain high Chl content [62], essential for photosynthesis, and higher Chl content that is lower reduction due to DS in wheat genotypes is voted as tolerant genotypes [61]. In addition, Chl has been regarded as a vital chloroplast component, which is crucial for photosynthesis and photosynthetic rate [63]. It is an indicator of the photosynthetic activity, biosynthesis of assimilates [64], and senescence [65]. However, the Chl content in flag leaves of wheat genotypes was significantly influenced by water regimes at 8 and 24 DAA (Table 7). Due to DS, the Chl content was remarkedly reduced in all wheat genotypes at $8 \mathrm{DAA}$, and the reduction was lesser in genotypes BAW $1169(8.40 \%)$ and BAW 1158 (9.76\%) compared to BAW $1158(16.60 \%)$ and BARI Gom $26(17.25 \%)$. The Chl content at 24 DAA was also profoundly reduced due to DS in all wheat genotypes following previous trends, and the reduction was minimum in BAW 1169 (14.85\%) and BAW 1158 (15.91\%) than BAW 1158 (32.56\%) and BARI Gom 26 (33.97\%). The rate of reduction due to DS at 24 DAA was higher than 8 DAA, as the plants suffer adversely owing to DS at a later stage with the depletion of 
soil moisture. The result obtained from this study indicated that genotypes BAW 1169 and BAW 1169 possessed higher content of $\mathrm{Chl}$ at both observation stages than the remaining genotypes under DS. Chl content in the flag leaves of barley decreased under DS [66], and a more pronounced reduction is noted in drought susceptible wheat genotypes [67]. The inhibition of $\mathrm{Chl}$ synthesis and the inability of sensitive wheat genotypes to withstand DS has been noted [68]. Our results contradict the earlier findings [69] as they reported that the $\mathrm{Chl}$ content in the stressed leaves of wheat increased as compared to non-stressed leaves, and this may happen under moderate water stress. Acute DS hampers photosynthesis by destroying $\mathrm{Chl}$ components, damaging the photosynthetic systems, along with decreasing the uptake of nutrients from soil solution and translocation within crop plants [63,70]. Furthermore, DS also damages the thylakoid membranes [71], adversely affecting Chl synthesis, accumulation, and distribution of assimilates [72]. The Chl content of the leaf may be used as an index for source evaluation; therefore, $\mathrm{Chl}$ content decline under DS has been considered as a pronounced non-stomatal limiting factor [73]. Additionally, Chl content has been recognized as an index to determine plants tolerance to DS [74], Chl reduction in response to water deficit is regarded as a sign of oxidative stress damage caused by chlorophyllase enzymes [75]. Furthermore, proline biosynthesis from glutamate precursor may also be inferred as the reason to decrease the Chl content under DS [76], as observed in our research (Tables 8 and 9). From overall information, it may be concluded that BAW 1169 is a tolerant genotype since it contains the highest amount of Chl than the other genotypes.

Table 7. Effect of DS on the flag leaf chlorophyll content of different wheat genotypes at 8 and 24 DAA.

\begin{tabular}{|c|c|c|c|c|c|}
\hline \multirow{2}{*}{ Genotypes } & \multirow{2}{*}{ Water Levels } & \multicolumn{2}{|c|}{ Chlorophyll Content in Flag Leaf at 8 DAA } & \multicolumn{2}{|c|}{ Chlorophyll Content in Flag Leaf at 24 DAA } \\
\hline & & $\mathrm{mg} \mathrm{g}^{-1} \mathrm{FW}$ & $\%$ Change Over Normal & $\mathrm{mg} \mathrm{g}^{-1} \mathrm{FW}$ & \% Change Over Normal \\
\hline \multirow{2}{*}{ BARI Gom 26} & Well watered & $2.55 \mathrm{a}$ & - & $2.09 \mathrm{~b}$ & - \\
\hline & Water stress & $2.11 \mathrm{~cd}$ & -17.25 & $1.38 \mathrm{~d}$ & -33.97 \\
\hline \multirow{2}{*}{ BAW 1158} & Well watered & $2.44 \mathrm{~b}$ & - & $2.20 \mathrm{a}$ & - \\
\hline & Water stress & $2.20 \mathrm{c}$ & -9.76 & $1.85 \mathrm{c}$ & -15.91 \\
\hline \multirow{2}{*}{ BAW 1167} & Well watered & $2.49 \mathrm{~b}$ & - & $2.15 \mathrm{ab}$ & - \\
\hline & Water stress & $2.06 \mathrm{~d}$ & -16.60 & $1.45 \mathrm{~d}$ & -32.56 \\
\hline \multirow{2}{*}{ BAW 1169} & Well watered & $2.62 \mathrm{a}$ & - & $2.29 \mathrm{a}$ & - \\
\hline & Water stress & $2.40 \mathrm{bc}$ & -8.40 & $1.95 \mathrm{bc}$ & -14.85 \\
\hline \multicolumn{2}{|c|}{ Level of significance } & $* *$ & & * & \\
\hline \multicolumn{2}{|c|}{$\mathrm{CV}(\%)$} & 2.20 & & 3.50 & \\
\hline
\end{tabular}

In a column, values having same letter(s) did not differ significantly by DMRT at $p \leq 5 \%$ level; DAA indicates days after anthesis, FW indicates fresh weight; ${ }^{*}$ indicates significant at $5 \%$ level of probability; ${ }^{* *}$ indicates significant at $1 \%$ level of probability.

\subsubsection{Canopy Temperature Depression (CTD)}

The CTD has been considered a reliable tool to assess drought tolerance in crop plants. It entails difference between air (ambient) temperature (Ta) and leaf (canopy) temperature (Tc), while the higher CTD values indicate better stress tolerance. Under DS, plants strive to adapt resistance strategies by a descending trend of physiological indices such as RWC, Chl content, $\mathrm{CTD}{ }^{\circ} \mathrm{C}$, etc., for minimizing the loss of water [77]. However, DS pronouncedly influenced CTD at 16 exhibited by wheat genotypes (Table 8 ). Wheat genotypes under WW condition maintained 8.60 to $9.53^{\circ} \mathrm{C}$ CTD, and the highest CTD was recorded in BAW 1169 $\left(9.53{ }^{\circ} \mathrm{C}\right)$, which was statistically similar to BARI Gom $26\left(9.40{ }^{\circ} \mathrm{C}\right)$, while BAW 1158 showed the lowest $\mathrm{CTD}\left(8.60^{\circ} \mathrm{C}\right)$ that was statistically equal to BAW $1167\left(8.73^{\circ} \mathrm{C}\right)$. The DS condition significantly reduced CTD values wheat genotypes under investigation, as the reduction was more pronounced in BAW 1167 (41.23\%), indicating its drought sensitivity followed by BARI Gom 26 (36.49\%), and the lowest was in BAW 1169 (23.71\%), signifying the most tolerant genotype. The results from this study indicated that BAW 1167 and BARI Gom 26 were more affected than BAW 1169 and BAW 1158. The CTD decrease under drought stress is probably due to an increase in respiration and a decrease in transpiration as a result of stomatal closure. These results are consistent with previously reported 
results in which DS significantly influenced the CTD of wheat genotypes. In addition, Tc has been regarded as vital indicator of water status in crop plants and holds merit for being a non-destructive technique for estimating stomatal conductance alterations under DS [78]. The water transpiration increment in response to moisture scarcity can decrease the temperature of plant surfaces and vice-versa [79]. Stressed wheat plants showed higher Tc in comparison to optimally watered plants [80]. Relatively lower Tc observed in DS plants indicates potential for absorbing higher soil moisture that assists plant to maintain optimal water status [81]. Our results indicated that the genotypes BAW 1169 and BAW 1158 (tolerant) exhibited cooler canopy in response to DS in comparison to the genotypes BAW 1167 and BARI Gom 26 (sensitive).

Table 8. Effect of DS on the CTD of different wheat genotypes at 16 DAA.

\begin{tabular}{|c|c|c|c|}
\hline \multirow{2}{*}{ Genotypes } & \multirow{2}{*}{ Water Levels } & \multicolumn{2}{|c|}{ Canopy Temperature Depression (CTD) } \\
\hline & & $\left({ }^{\circ} \mathrm{C}\right)$ & $\%$ Change Over Control \\
\hline \multirow[b]{2}{*}{ BARI Gom 26} & WW & $9.40 \mathrm{ab}$ & - \\
\hline & DS & $5.97 \mathrm{e}$ & -36.49 \\
\hline \multirow{2}{*}{ BAW 1158} & WW & $8.60 \mathrm{c}$ & - \\
\hline & DS & $6.30 \mathrm{e}$ & -26.74 \\
\hline \multirow{2}{*}{ BAW 1167} & WW & $8.73 \mathrm{bc}$ & - \\
\hline & DS & $5.13 \mathrm{f}$ & -41.23 \\
\hline \multirow{2}{*}{ BAW 1169} & WW & $9.53 \mathrm{a}$ & - \\
\hline & DS & $7.27 \mathrm{~d}$ & -23.71 \\
\hline \multicolumn{2}{|c|}{ Level of significance } & $* *$ & - \\
\hline \multicolumn{2}{|c|}{ CV $(\%)$} & 3.82 & - \\
\hline
\end{tabular}

In a column, values having same letter(s) did not differ significantly by DMRT at $p \leq 5 \%$ level; ** indicates significant at $1 \%$ level of probability.

\subsubsection{Proline Content}

Proline accumulation under DS is one of the common features in plants [82], which serves as critical osmolyte biosynthesized in response to abiotic stresses, including DS [83]. Generally, genotypes are selected as drought-tolerant, having higher proline content in DS than in normal conditions. However, flag leaves proline content varied among wheat genotypes at 16 DAA under DS (Table 9). The proline content in flag leaves was increased in all genotypes due to DS, and the highest increment was recorded in BAW $1169(24.02 \%)$ over BAW 1158 (21.55\%), BARI Gom 26 (10.53\%), and BAW 1167 (8.19\%), respectively. The proline content in the kernel was also increased in all the genotypes due to the influence of DS. The highest increment over control (WW) was recorded in BAW $1169(20.16 \%)$, followed by BAW $1158(18.00 \%)$, and the lowest was in BAW 1167 (3.54\%), trailed by BARI Gom 26 $(4.25 \%)$. The results indicated that BAW 1169 and BAW 1158 maintained the maximum amount of proline content in the flag leaf and kernel than BARI Gom 26 and BAW 1167 genotypes under DS conditions. The proline content in bread wheat genotypes significantly increased under stress, as reported in earlier research [84]. In addition, plant cells achieve osmotic adjustment by accumulating compatible solutes such as proline in the cytoplasm and serve as an osmoprotectant [85]. It helps to control N storage, stabilize membrane, and scavenge different free radicals, along with buffering cellular redox potential to cope with abiotic stresses [86]. Under DS, proline performs role of metal chelator, antioxidative protection and signaling [83]. The accumulation of proline in DS plants can also serve as sensor of drought injury along with its prime role in stress tolerance mechanisms [84]. It has the potential to protect crop plants from oxidative damage, which is the main strategy of plants to avoid detrimental effects of water deficit stress. High proline levels enable plants to attain low water potential, and thus imparts tolerance against moisture deficiency by increasing the biosynthesis of intermediate enzymes [85]. In a recent study, it was observed that wheat genotypes alleviate DS by overproduction of two special amino acids, namely L-cysteinylglycine and fructoselysine, to tolerate drought [14]. The plants' potential for accumulating the proline under DS depends on genetic potential of variety along with 
severity and duration of stresses. Few plant species have potential to biosynthesize enough proline to cope with adverse effects of abiotic stresses [86]. However, the genetic disparity of such osmotic changes can be a useful tool for the selection of drought-tolerant wheat genotypes [87]. Higher accumulation of proline content in BAW 1169 and BAW 1158 due to DS indicates as relatively tolerant genotypes, and it may be associated to better osmotic adjustment of plants, which prevents degradation of macromolecules and different vital cell membranes [59,88].

Table 9. Effect of DS on the proline content in flag leaf and kernel of wheat genotypes at 16 DAA.

\begin{tabular}{|c|c|c|c|c|c|}
\hline \multirow{2}{*}{ Genotypes } & \multirow{2}{*}{ Water Levels } & \multicolumn{2}{|c|}{ Proline Content in Flag Leaf } & \multicolumn{2}{|c|}{ Proline Content in Kernel } \\
\hline & & $\mu$ mole $\mathrm{g}^{-1} \mathrm{FW}$ & \% Change Over Normal & $\mu$ mole $\mathrm{g}^{-1} \mathrm{FW}$ & $\%$ Change Over Normal \\
\hline \multirow{2}{*}{ BARI Gom 26} & Well watered & $1.90 \mathrm{c}$ & - & $2.60 \mathrm{~cd}$ & - \\
\hline & Water stress & $2.10 \mathrm{a}$ & 10.53 & $2.71 \mathrm{c}$ & 4.25 \\
\hline \multirow{2}{*}{ BAW 1158} & Well watered & $1.81 \mathrm{~d}$ & - & $2.50 \mathrm{~d}$ & - \\
\hline & Water stress & $2.20 \mathrm{a}$ & 21.55 & $2.95 \mathrm{~b}$ & 18.00 \\
\hline \multirow{2}{*}{ BAW 1167} & Well watered & $1.83 \mathrm{~d}$ & - & $2.54 \mathrm{~d}$ & - \\
\hline & Water stress & $1.99 \mathrm{~b}$ & 8.19 & $2.64 \mathrm{c}$ & 3.94 \\
\hline \multirow{2}{*}{ BAW 1169} & Well watered & $1.79 \mathrm{~d}$ & - & $2.58 \mathrm{~d}$ & - \\
\hline & Water stress & $2.22 \mathrm{a}$ & 24.02 & $3.10 \mathrm{a}$ & 20.16 \\
\hline \multicolumn{2}{|c|}{ Level of significance } & * & & * & \\
\hline \multicolumn{2}{|c|}{ CV $(\%)$} & 4.04 & & 2.56 & \\
\hline
\end{tabular}

In a column, values having same letter(s) did not differ significantly by DMRT at $p \leq 5 \%$ level; FW indicates fresh weight; * indicates significant at $1 \%$ level of probability.

\subsection{Accumulation of Photo-Assimilates}

\subsubsection{Spike Dry Matter (SDM)}

Under optimal and moisture scarce conditions, a sigmoid way for accumulation of dry matter (DM) in spike was noted in wheat genotypes (Figure 1). Under WW conditions, the ear DM weight was observed to increase gradually in BARI Gom 26 (4.57 g) followed by BAW 1158 (4.03 g) and BAW 1167 (3.98 g) at 44 DAA, the last observing stage in this study. The remaining BAW 1169 genotype was observed to increase in SDM weight ( $3.56 \mathrm{~g}$ ) up to 40 DAA, and thereafter declined. Under DS, the DM accumulation in the spike increased in all wheat genotypes up to a certain DAA, such as BARI Gom 26 and BAW 1158, which increased up to 40 DAA and then declined, and BAW 1167 increased up to 36 DAA and thereafter declined tremendously. Whereas, in the case of BAW 1169, the DM increased gradually with increasing plant age (DAA). The declining tendency of $\mathrm{DM}$ after attaining the highest level may be due to respiratory loss of spike. Hence, it is indicated that the wheat grains of BAW 1167, BARI Gom 26, and BAW 1158 dried quickly and attained physiological maturity earlier as compared to BAW 1169. The sigmoid way involving accumulation of dry matter under DS has also been reported earlier $[69,89]$. The DS condition leads to reduced plant growth, which is reflected in plant height, leaf area, dry weight, and other growth functions [42,90], reduced Chl content, photosynthetic rate, and $\operatorname{TDM}[14,39,91]$. The reduction of SDM may be attributed to profound respiratory losses in the spike. DS in crop field decreased $\mathrm{CO}_{2}$ uptake [92], leaf gas exchange capacity [93], and photochemical reactions and photosynthetic metabolism [94]; consequently, these might have reduced DM in plants. Our results showed that DS reduced the RWC (Table 6), Chl content (Table 7), and CTD (Table 8), resulting in reduced SDM; BAW 1169 maintained higher values among all genotypes under DS. 


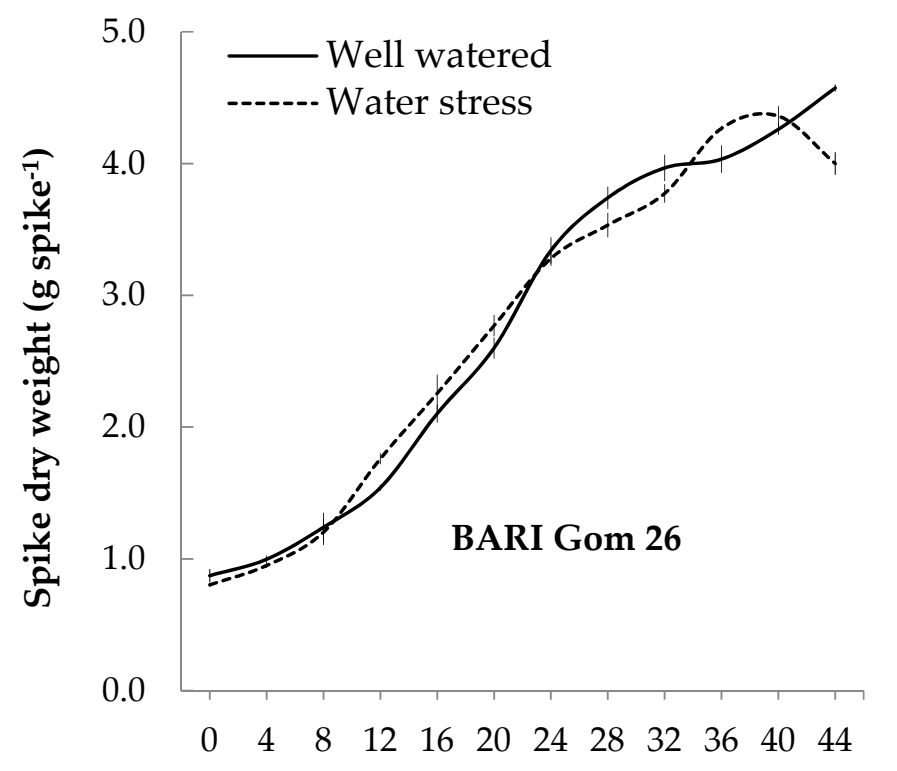

Days after anthesis

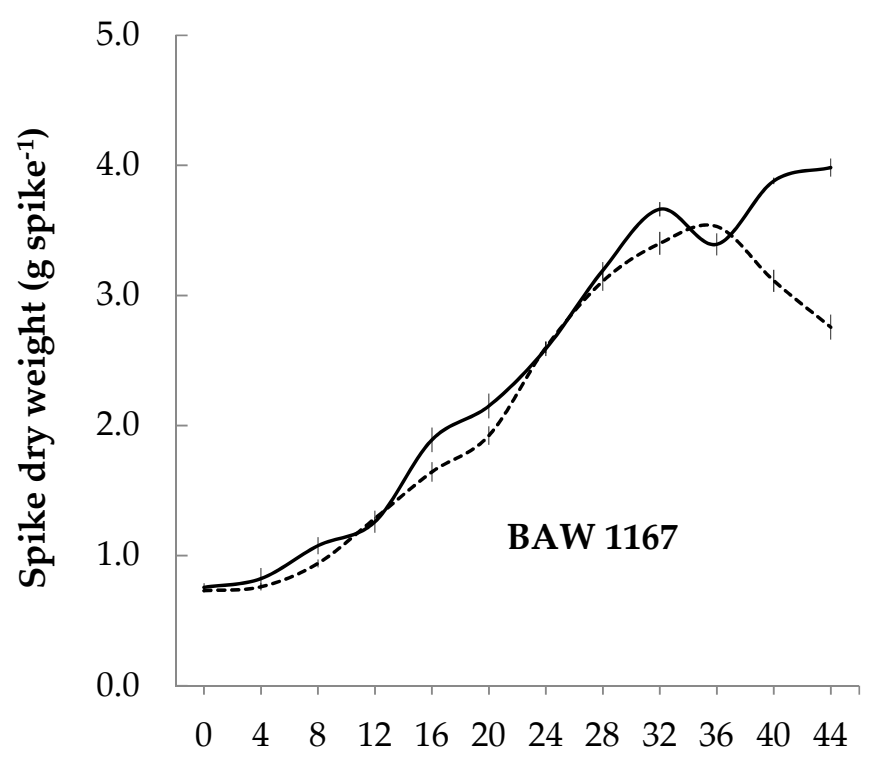

Days after anthesis

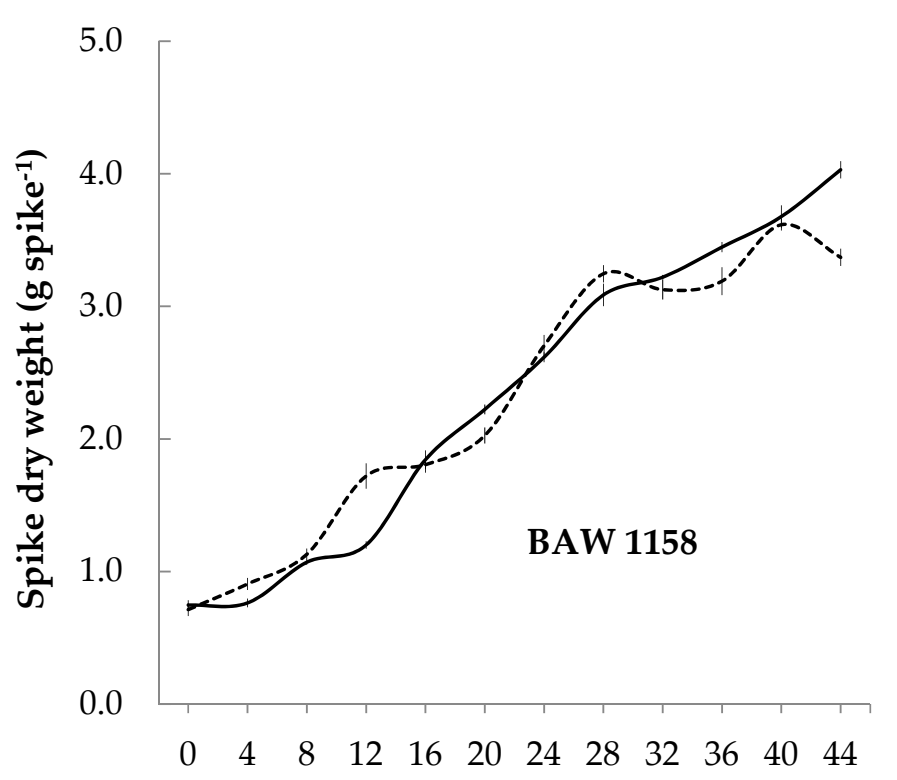

Days after anthesis

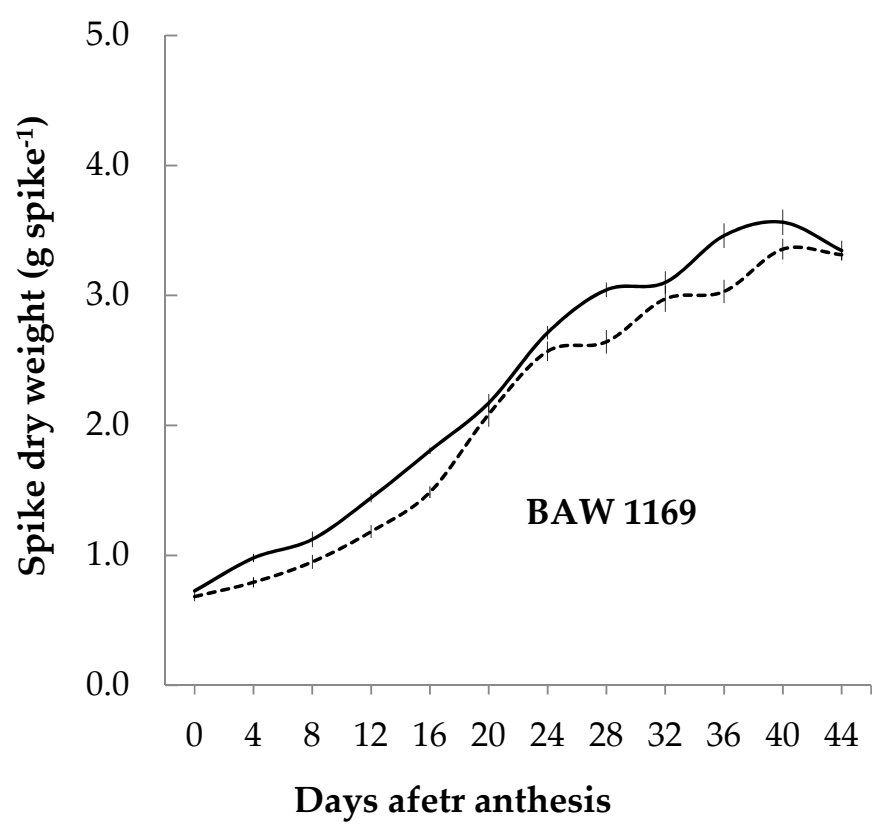

Figure 1. Effect of DS on the spike dry weight of different wheat genotypes at different DAA.

\subsubsection{Dry Weight of Grains Spike ${ }^{-1}$}

Significant variation was found in grain dry weight spike ${ }^{-1}$ by the interaction effect of water levels and wheat genotypes (Table 10). At WW condition, BARI Gom 26 produced the maximum dry weight of grains spike ${ }^{-1}\left(3.45 \mathrm{~g}\right.$ spike $\left.{ }^{-1}\right)$, while the lowest corresponding value was recorded for BAW 1158 (2.96 g spike $\left.{ }^{-1}\right)$, which was statistically similar to BAW 1167 (2.97 $\left.\mathrm{g}^{\text {spike }}{ }^{-1}\right)$. In DS, the grain dry weight spike ${ }^{-1}$ was reduced significantly in all wheat genotypes, and the degree of reduction was maximum in BAW 1167 $(11.78 \%)$ followed by BARI Gom $26(8.33 \%)$ than that of BAW $1169(3.26 \%)$ and BAW 1158 $(3.38 \%)$. The results indicated that genotypes BAW 1169 and BAW 1158 were relatively less affected by water deficit stress than the other two genotypes. DS leads to reduced plant growth reflected in leaf area, dry weight, spike length, number of grains spige ${ }^{-1}$ and grain weight $[39,42,89,90]$. High Chl content under DS indicates lower intensity of 
photosynthetic apparatus's photo-inhibition, therefore decreasing losses of carbohydrates for grains development [95]. A higher number of the fertile floret, which is transferred into a higher number of potential grain spike ${ }^{-1}$, may depend on several factors under DS such as reduced phenological indices (Table 5), RWC (Table 6), Chl content (Table 7) etc., consequently reduced grain size, and finally reduced grain weight spike ${ }^{-1}$ greatly in BAW 1167 and BARI Gm 26. Most likely at the sink level, DS adversely affects the grain yield potential by decreasing fertile grains and the size spike ${ }^{-1}$ in BAW 1167 and BARI Gm 26 (sensitive) genotypes.

Table 10. Effect of DS on the grain dry weight spike $\mathrm{s}^{-1}$ and grain yield of different wheat genotypes.

\begin{tabular}{|c|c|c|c|c|c|}
\hline \multirow{2}{*}{ Genotypes } & \multirow{2}{*}{ Water Levels } & \multicolumn{2}{|c|}{ Grain Dry Weight Spike ${ }^{-1}$} & \multicolumn{2}{|c|}{ Grain Yield } \\
\hline & & g Spike $^{-1}$ & \% Change Over Normal & tha ${ }^{-1}$ & $\%$ Change Over Normal \\
\hline \multirow{2}{*}{ BARI Gom 26} & Well watered & $3.60 \mathrm{a}$ & & $5.58 \mathrm{a}$ & - \\
\hline & Water stress & $3.30 \mathrm{~b}$ & -8.33 & $3.64 \mathrm{~d}$ & -34.77 \\
\hline \multirow{2}{*}{ BAW 1158} & Well watered & $2.82 \mathrm{~d}$ & - & $5.56 \mathrm{a}$ & - \\
\hline & Water stress & $2.76 \mathrm{~d}$ & -2.13 & $4.23 \mathrm{c}$ & -23.92 \\
\hline \multirow{2}{*}{ BAW 1167} & Well watered & $2.97 \mathrm{c}$ & - & $5.07 \mathrm{~b}$ & - \\
\hline & Water stress & $2.62 \mathrm{e}$ & -11.78 & $3.27 \mathrm{~d}$ & -35.50 \\
\hline \multirow{2}{*}{ BAW 1169} & Well watered & $3.07 \mathrm{c}$ & - & $5.65 \mathrm{a}$ & - \\
\hline & Water stress & $2.97 \mathrm{c}$ & -3.26 & $4.39 \mathrm{c}$ & -22.30 \\
\hline \multicolumn{2}{|c|}{ Level of significance } & $* *$ & - & $* *$ & - \\
\hline \multicolumn{2}{|c|}{$\mathrm{CV}(\%)$} & 1.88 & - & 2.67 & - \\
\hline
\end{tabular}

In a column, values having same letter(s) did not differ significantly by DMRT at $p \leq 5 \%$ level ** indicates significant at $1 \%$ level of probability.

\subsubsection{Grain Yield}

The grain yield of wheat genotypes was significantly influenced by water conditions in the field (Table 10). At WW condition, the grain yield ranged from 5.65 to $5.07 \mathrm{t} \mathrm{ha}^{-1}$, while BAW 1169 provided the highest yield $\left(5.65 \mathrm{t} \mathrm{ha}^{-1}\right)$, which was statistically identical to BARI Gom $26\left(5.58 \mathrm{tha}^{-1}\right)$, and BAW $1158\left(5.56 \mathrm{tha}^{-1}\right)$. The lowest yield was found in BAW $1167\left(5.07 \mathrm{tha}^{-1}\right)$. Grain yield was reduced in all wheat genotypes due to DS, and the extent of reduction was maximum in BAW $1167(35.50 \%)$ and BARI Gom $26(34.77 \%)$ than BAW $1169(22.30 \%)$ and BAW 1158 (23.92\%) over control (WW), indicating that the two previous genotypes were more susceptible to DS. The results indicated that less reduction of grain yield in BAW 1169 and BAW 1158 genotypes owing to DS was a result of drought tolerance. Other studies also showed that a stress environment reduces grain yield in wheat compared to control $[33,96]$. DS had unusual effects on the grain yield, depending on the developmental stage in which it occurs. TGW and grain yield were remarkably reduced when DS was imposed at pre-anthesis, post-anthesis, anthesis, booting, and anthesis with reduced grain-filling period $[39,97]$. Significant reduction in grain yield due to postanthesis water stress may result from a reduction of the production of photo-assimilates (source limitation), power of the sink to absorb photo-assimilates and the grain filling duration. DS at post-anthesis severely reduced grain yield (98\%), which depends upon the severity of stress and growth stage in which the drought condition was imposed [96,98]. The improvement of yield in wheat and barley under DS has resulted from a prolonged grain filling period, high chlorophyll content, and a more sustained turgor or combination of them [99]. The incidence of DS at early and later growth stages severely affected wheat growth, which alters water-utilizing capacity and ultimately results in substantially reduced yield [100]. The anthesis stage is highly vulnerable to DS as it affects the pollen grain viability, which in turn, reduces the number of grains spike ${ }^{-1}$ [101]. The highest grain yield in BAW 1169 and BAW 1158 under DS in this study may be related to less reduction of life span (Table 5), RWC (Table 6), total Chl (Table 7), CTD (Table 8), SDM (Figure 1) and increasing proline (Table 9), as supported by many researchers $[86,88,102,103]$. The yield variation under DS can be attributed to the diverse genetic background among the 
genotypes [103-105], and activated genes in response to drought exhibited variation in their expression [106].

\section{Conclusions}

In this study, the drought stress remarkably decreased the phenological indices such as days to booting, heading, anthesis, etc. in all wheat genotypes. However, the reduction was comparatively lower in BAW 1169 and BAW 1158 genotypes than BAW 1167 and BARI Gom 26 indicating their superiority in terms of drought tolerance. In addition, better RWC, Chl and proline contents in flag leaf and kernel along with CTD were noted in BAW 1169 and BAW 1158 genotypes. Furthermore, yield attributes including SDM and grain weight spike ${ }^{-1}$, along with grain yield, were significantly reduced in BAW 1167 and BARI Gom 26 genotypes than that of BAW 1169 and BAW 1158. Finally, longer growth duration, greater stability of flag leaf chlorophyll, water retention capability in leaves, ability to keep the canopy cooler, higher proline level, greater SDM, and better grains spike $^{-1}$ under DS contributed to drought tolerance of wheat genotypes, which might be inferred to be ranked as BAW 1169 > BAW $1158>$ BARI Gom 26 > BAW 1167 in decreasing order of drought tolerance.

Author Contributions: Conceptualization, M.A.H. (M. A. Hasan), M.M.B., and M.K.C.; methodology, M.A.H. (M. A. Hasan) and M.K.C.; software, M.A.H. (M. A. Hasan) and M.K.C.; validation, M.A.H. (M. A. Hasan), M.K.C., M.M.B., and M.S.I.; formal analysis, M.A.H. (M. A. Hasan) and M.K.C.; investigation, M.K.C., and M.A.H. (M. A. Hasan); resources, M.A.H. (M. A. Hasan); data curation, M.K.C., M.A.H. (Md. Abdul Hakim), M.R.I. (Md. Rafiqul Islam), and M.S.I.; writing-original draft preparation, M.K.C., M.A.H. (M. A. Hasan), and M.S.I.; writing-review and editing, T.J., R.S., A.R., M.S.I., S.S., M.R.I., M.A.I., M.M.B., M.A.H. (Md. Abdul Hakim), A.R., S.A. (Sultana Anwar), and N.E.M.E.; visualization, M.S.I.; supervision, M.A.H. (M. A. Hasan); project administration, M.A.H. (M. A. Hasan); funding acquisition, S.A. (Sultana Anwar), S.A. (Saud Alamri), M.S.I., M.M.B., N.E.M.E. and A.E.S. All authors have read and agreed to the published version of the manuscript.

Funding: Researchers supporting project number (RSP-2021/194), King Saud University, Riyadh, Saudi Arabia.

Institutional Review Board Statement: Not applicable.

Informed Consent Statement: Not applicable.

Data Availability Statement: Not applicable.

Acknowledgments: The authors would like to extend their sincere appreciation to the researchers supporting project number (RSP-2021/194), King Saud University, Riyadh, Saudi Arabia.

Conflicts of Interest: The authors declare no conflict of interest.

\section{References}

1. Irshad, M.; Ullah, F.; Fahad, S.; Mehmood, S.; Khan, A.U.; Brtnicky, M.; Kintl, A.; Holatko, J.; Irshad, I.; El-Sharnouby, M.; et al. Evaluation of Jatropha curcas L. leaves mulching on wheat growth and biochemical attributes under water stress. BMC Plant Biol. 2021, 21, 303. [CrossRef]

2. Asseng, S.; Foster, I.; Turner, N.C. The impact of temperature variability on wheat yields. Glob. Chang. Biol. 2011, 17, 997-1012. [CrossRef]

3. EL Sabagh, A.; Islam, M.S.; Skalicky, M.; Raza, M.A.; Singh, K.; Anwar Hossain, M.; Hossain, A.; Mahboob, W.; Iqbal, M.A.; Ratnasekaera, D.; et al. Salinity Stress in Wheat (Triticum aestivum L.) in the Changing Climate: Adaptation and Management Strategies. Fron. Agron. 2021, 3, 43.

4. Karim, M.A.; Hamid, A.; Rahman, S. Grain growth and yield performance of wheat under subtropical conditions: II. Effect of water stress at reproductive stress. Cereal Res. Comm. 2000, 28, 101-107. [CrossRef]

5. Raza, A.; Mehmood, S.S.; Shah, T.; Zou, X.; Yan, L.; Zhang, X.; Khan, R.S.A. Applications of molecular markers to develop resistance against abiotic stresses in wheat. In Wheat Production in Changing Environments; Springer: Singapore, 2019; pp. 393-420. [CrossRef]

6. Kramer, P.J. Water Relation of Plants; Academic Press: Orlando, FL, USA, 1983; pp. 342-389. Available online: http://www. sciencedirect.com/science/book/9780124250406 (accessed on 6 September 2021). 
7. Araus, J.L.; Slafer, G.A.; Reynolds, M.P.; Royo, C. Plant Breeding and Drought in C3 Cereals: What Should We Breed For? Ann. Bot. 2002, 89, 925-940. [CrossRef]

8. Mitra, J. Genetics and genetic improvement of drought resistance in crop plants. Curr. Sci. 2001, 80, 758-763.

9. Datta, J.; Mondal, T.; Banerjee, A.; Mondal, N. Assessment of drought tolerance of selected wheat cultivars under laboratory condition. J. Agric. Technol. 2011, 7, 383-393.

10. Nowsherwan, I.; Shabbir, G.; Malik, S.I.; Ilyas, M.; Iqbal, M.S.; Musa, M. Effect of drought stress on different physiological traits in bread wheat. SAARC J. Agric. 2018, 16, 1-6. [CrossRef]

11. Bayoumi, T.Y.; Eid, M.H.; Metwali, E.M. Application of physiological and biochemical indices as a screening technique for drought tolerance in wheat genotypes. Afr. J. Biotechnol. 2008, 7, 2341-2352.

12. Dawood, M.F.A.; Abeed, A.H.A.; Aldaby, E.E.S. Titanium dioxide nanoparticles model growth kinetic traitsof some wheat cultivars under different water regimes. Indian J. Plant Physiol. 2019, 24, 129-140. [CrossRef]

13. Bowne, J.B.; Erwin, T.A.; Juttner, J.; Schnurbusch, T.; Langridge, P.; Bacic, A.; Roessner, U. Drought responses of leaf tissues from wheat cultivars of differing drought tolerance at the metabolite level. Mol. Plant 2012, 5, 418-429. [CrossRef]

14. Guo, X.; Xin, Z.; Yang, T.; Ma, X.; Zhang, Y.; Wang, Z.; Ren, Y.; Lin, T. Metabolomics Response for Drought Stress Tolerance in Chinese Wheat Genotypes (Triticum aestivum). Plants 2020, 9, 520. [CrossRef]

15. Hussain, H.A.; Hussain, S.; Khaliq, A.; Ashraf, U.; Anjum, S.A.; Men, S.; Wang, L. Chilling and Drought Stresses in Crop Plants: Implications, Cross Talk, and Potential Management Opportunities. Front. Plant Sci. 2018, 9, 393. [CrossRef]

16. Raza, A.; Charagh, S.; Sadaqat, N.; Jin, W. Arabidopsis thaliana: Model plant for the study of abiotic stress responses. In The Plant Family Brassicaceae; Springer: Singapore, 2020; pp. 129-180. [CrossRef]

17. Blum, A.; Pnuel, Y. Physiological attributes associated with drought resistance of wheat cultivars in a Mediterranean environment. Aust. J. Agric. Res. 1990, 41, 799-810. [CrossRef]

18. FAO-UNDP. Land Resources Appraisal of Bangladesh for Agricultural Development: Agro-Ecological Regions of Bangladesh; Technical Report No. 3, Volume II; United Nations Development Programme (UNDP)-Food and Agriculture Organization (FAO): Rome, Italy, 1988.

19. BARC (Bangladesh Agricultural Research Council). Fertilizer Recommendation Guide: Agroecological Regions of Bangladesh; Bangladesh Agricultural Research Council: Dhaka, Bangladesh, 2012; p. 251.

20. Zadoks, J.C.; Chang, T.T.; Konzak, C.F. A decimal code for the growth stages of cereals. Weed Res. 1974, 14, 415-421. [CrossRef]

21. Barr, H.D.; Weatherley, P.E. A reexamination of the relative turgidity technique for estimating water deficit in leaves. Aust. J. Biol. Sci. 1962, 15, 413-428. [CrossRef]

22. Witham, H.; Blades, D.F.; Devin, R.H. Exercise in Plant Physiology, 2nd ed.; PWS Publishers: Boston, MA, USA, $1986 ;$ pp. 128-131.

23. Ayeneh, A.; Ginkel, M.; Reynolds, M.P.; Ammar, K. Comparison of leaf, spike, peduncle, and canopy temperature depression in wheat under heat stress. Field Crop. Res. 2002, 79, 173184. [CrossRef]

24. Bates, L.S.; Waldren, R.P.; Teare, I.D. Rapid determination of free proline for water stress studies. Plant Soil 1973, 39, 205-207. Available online: https:/ /link.springer.com/article/10.1007/BF00018060 (accessed on 6 September 2021). [CrossRef]

25. Gomez, K.A.; Gomez, A.A. Statistical Procedure for Agricultural Research, 2nd ed.; John Wiley \& Sons: Los Baños, Philippines, 1984; pp. 28-192.

26. Maman, N.; Lyon, D.J.; Mason, S.; Galusha, T.D.; Higgins, R. Pearl millet and grain sorghum yield response to water supply in Nebraska. Panhand. Res. Ext. Cent. 2003, 8. [CrossRef]

27. Sokoto, M.B.; Abubakar, I.U.; Singh, A. Effect of Water Stress and Variety on Phenology of Bread Wheat (Triticumaestivum L.) in Sokoto, Sudan Savannah, Nigeria. J. Dryland Agric. 2015, 1, 33-43.

28. Riaz, R. Genetic Analysis for Yield and Yield Components in Spring Wheat under Drought Conditions. Ph.D. Thesis, Department of Agriculture, Faisalabad Agriculture University, Faisalabad, Pakistan, 2003; p. 35.

29. Majer, P.; Sass, L.; Lelley, T.; Cseuz, L.; Vass, I.; Dudits, D.; Pauk, J. Testing drought tolerance of wheat by a complex stress diagnostic system installed in greenhouse. Acta Biol. Szeged. 2008, 52, 97-100.

30. Bilal, M.; Rashid, R.; Rehman, S.; Iqbal, F.; Ahmed, J.; Abid, M.; Ahmed, Z.; Hayat, A. Evaluation of wheat genotypes for drought tolerance. J. Green Physiol. Genet. Genom. 2015, 1, 11-21.

31. Allahverdiyev, T.I. Effect of drought stress on some physiological parameters, yield, yield components of durum (Triticum durum desf.) and bread (Triticum aestivum L.) wheat genotypes. Ekin J. Crop Breed. Genet. 2015, 1, 50-62.

32. Siddique, K.H.M.; Tennant, D.; Perry, M.W.; Belford, R.K. Water use and water use efficiency of old and modern wheat cultivars in a Mediterranean-type environment. Aust. J. Agril. Res. 1990, 41, 431-447. [CrossRef]

33. Poudel, M.R.; Ghimire, S.; Pandey, M.P.; Dhakal, K.H.; Thapa, D.B.; Poudel, H.K. Evaluation of Wheat Genotypes under Irrigated, Heat Stress and Drought Conditions. J. Biol. Today's World 2020, 9, 212.

34. Khakwani, A.A.; Dennett, M.D.; Munir, M.; Abid, M. Growth and yield response of wheat varieties to water stress at booting and anthesis stages of development. Pak. J. Bot. 2012, 44, 879-886.

35. Siddique, K.H.M.; Loss, S.P.; Thomson, B.D.; Saxena, N.P. Cool season grain legumes in dryland Mediterranean environments of Western Australia: Significance of early flowering. In Management of Agricultural Drought: Agronomic and Genetic Options; Saxena, N.P., Ed.; Oxford University Press: New Delhi, India, 2003; pp. 151-162.

36. Kirda, C.; Kanber, R.; Tulucu, K. Yield response of cotton, maize, soybean, sugar beet, sunflower, and wheat to deficit irrigation. In Crop Yield Response to Deficit Irrigations; Kluwer Academic: Dordrecht, The Netherlands, 1999; pp. 21-38. 
37. Gonzalez, A.; Bermejo, V.; Gimeno, B.S. Effect of different physiological traits on grain yield in barley grown under irrigated and terminal water deficit conditions. J. Agric. Sci. 2010, 148, 319-328. [CrossRef]

38. Lopes, M.S.; Reynolds, M.P. Stay-green in spring wheat can be determined by spectral reflectance measurements (normalized difference vegetation index) independently from phenology. J. Exp. Bot. 2012, 63, 3789. [CrossRef]

39. Mehraban, A.; Ahmad Tobe, A.; Gholipouri, A.; Amiri, E.; Ghafari, A.; MozffarRostaii, M. The Effects of Drought Stress on Yield, Yield Components, and Yield Stability at Different Growth Stages in Bread Wheat Cultivar (Triticum aestivum L.). Pol. J. Environ. Stud. 2019, 28, 739-746. [CrossRef]

40. Nezhadahmadi, A.; Prodhan, Z.; Faruq, G. Drought Tolerance in Wheat. Sci. World J. 2013, 2013, 610721. [CrossRef]

41. Rajala, A.; Hakala, K.; Mäkelä, P.; Peltonen-Sainio, P. Drought effect on grain number and grain weight at spike and spikelet level in six-row spring barley. J. Agron. Crop Sci. 2011, 197, 103-112. [CrossRef]

42. Kilic, H.; Yağbasanlar, T. The effect of drought stress on grain yield, yield components and some quality traits of durum wheat (Triticum turgidum) cultivars. Notulae Botanicae Horti Agrobotanici Cluj-Napoca 2010, 38, 164-170. [CrossRef]

43. Afzal, I.; Imran, S.; Javed, T.; Basra, S.M.A. Evaluating the integrative response of moringa leaf extract with synthetic growth promoting substances in maize under early spring conditions. S. Afr. J. Bot. 2020, 132, 378-387. [CrossRef]

44. Motzo, R.; Giunta, F. The Effect of breeding on the phenology of Italian durum wheats: From landraces to modern cultivars. Eur. J. Agron. 2007, 26, 462-470. [CrossRef]

45. Attarbashi, M.R.; Galeshi, S.; Soltani, A.; Zinali, E. Relationship of phenology and physiological traits with grain yield in wheat under rain-fed conditions. Iran. J. Agric. Sci. 2002, 33, 8-21.

46. Peterman, L.T.; Sears, R.G.; Kanemasu, E.T. Rate and duration of spikelet initiation in 10 winter wheat cultivar. Crop Sci. J. 1985, 25, 222-225. [CrossRef]

47. Sial, M.A.; Dahot, M.U.; Arain, M.A.; Markhand, G.S.; Naqvi, M.H.; Laghari, K.A.; Mirbahar, A.A. Effect of water stress on yield and yield components of semi-dwarf bread wheat (Triticum aestivum L.). Pak. J. Bot. 2009, 41, 1715-1728.

48. Belay, G.A.; Zhang, Z.; Xu, P. Physio-Morphological and Biochemical Trait-Based Evaluation of Ethiopian and Chinese Wheat Germplasm for Drought Tolerance at the Seedling Stage. Sustainability 2021, 13, 4605. [CrossRef]

49. Boyer, J.S.; James, R.A.; Munns, R.; Condon, T.; Passioura, J.B. Osmotic adjustment leads to anomalously low estimates of relative water content in wheat and barley. Funct. Plant Biol. 2008, 35, 1172-1182. [CrossRef] [PubMed]

50. Singh, J.; Patel, A.L. Water status, gaseous exchange, proline accumulation and yield of wheat un response to water stress. Ann. Biol. Ludhiana 1996, 12, 26-28.

51. Lonbani, M.; Arzani, A. Morpho-physiological traits associated with terminal drought-stress tolerance in triticale and wheat. Agron. Res. 2011, 9, 315-329.

52. Teulat, B.; Monneveux, P.; Wery, J.; Borries, C.; Souyris, I.; Charrier, A.; This, D. Relationships between relative water content and growth parameters under water stress in barley: A QTL study. New Phytol. 1997, 137, 99-107. [CrossRef]

53. Hasheminasab, H.; Assad, A.M.; Aliakbari, T.; Sahhafi, S.R. Evaluation of some physiological traits associated with improved drought tolerance in Iranian wheat. Ann. Biol. Res. 2012, 3, 1719-1725.

54. Colom, M.R.; Vazzana, C. Photosynthesis and PSII functionality of drought-resistant and drought sensitive weeping love grass plants. Environ. Exp. Bot. 2003, 49, 135-144. [CrossRef]

55. Sinclair, T.; Ludlow, M. Who taught plants thermodynamics? The unfulfilled potential of plant water potential. Aust. J. Plant Physiol. 1985, 12, 213-217. [CrossRef]

56. Tatar, O.; Gevrek, M.N. Influence of water stress on prolin accumulation, lipid peroxidation and water content of wheat. Asian J. Plant Sci. 2008, 7, 409-412. [CrossRef]

57. Siddique, M.R.B.; Hamid, A.; Aslam, M.S. Drought stress effects on water relations of wheat. Bot. Bull. Acad. Sin. 2000, 41, 35-39.

58. Ritchie, S.W.; Nguyan, H.T.; Holaday, A.S. Leaf Water content and gas exchange parameters of two wheat genotypes differing in drought resistance. Crop Sci. 1990, 30, 105-111. [CrossRef]

59. Ghassemi-Golezani, K.; Afkhami, N. Changes in some morpho-physiological traits of safflower in response to water deficit and nano-fertilizers. J. Bio. Environ. Sci. 2018, 12, 391-398.

60. Mamnabi, S.; Safar Nasrollahzadeh, S.; Ghassemi-Golezani, K.; Raei, M. Improving yield-related physiological characteristics of spring rapeseed by integrated fertilizer management under water deficit conditions. Saudi J. Biol. Sci. 2020, 27, 797-804. [CrossRef]

61. Schonfeld, M.A.; Johnson, R.C.; Carver, B.F.; Mornhinweg, D.W. Water relations in winter wheat as drought resistance indicators. Crop Sci. 1988, 28, 526-531. [CrossRef]

62. Almeselmani, M.; Abdullah, F.; Hareri, F.; Naaesan, M.; Ammar, M.A.; ZuherKanbar, O.; Saud, A.A. Effect of drought on different physiological characters and yield component in different varieties of Syrian durum wheat. J. Agric. Sci. 2011, 3, 127-133. [CrossRef]

63. Sairam, R.K.; Deshmukh, P.S.; Shukla, D.S. Increased Antioxidant Enzyme Activity in Response to Drought and Temperature Stress Related with Stress Tolerance in Wheat Genotypes. Abstract: National Seminar (ISSP); IARI: New Delhi, India, $1997 ;$ p. 69.

64. Manivannan, P.; Jaleel, C.A.; Sankar, B.; Kishorekumar, A.; Somasundaram, R.; Lakshmanan, G.A.; Panneerselvam, R. Growth, biochemical modifications and proline metabolism in Helianthus annuus L. as induced by drought stress. Colloids Surf. B Biointerfaces 2007, 59, 141-159. [CrossRef] [PubMed] 
65. Bijanzadeh, E.; Emam, Y. Effect of Defoliation and drought stress on yield components and chlorophyll content of wheat. Pak. J. Biol. Sci. 2010, 13, 699-705. [CrossRef]

66. Brown, S.B.; Houghton, J.D.; Hendry, G.A.F. Chlorophyll breakdown. In Chlorophyllus; Scheer, H., Ed.; CRC Press: Boca Raton, FL, USA, 1991; p. 465.

67. Javed, T.; Shabbir, R.; Ali, A.; Afzal, I.; Zaheer, U.; Gao, S.J. Transcription factors in plant stress responses: Challenges and potential for sugarcane improvement. Plants 2020, 9, 491. [CrossRef] [PubMed]

68. Farshadfar, E.; Ghasemi, M.; Rafii, F. Evaluation of physiological parameters as a screening technique for drought tolerance in bread wheat. J. Biodiv. Environ. Sci. 2014, 4, 175-186.

69. Sikuku, P.A.; Netondo, G.W.; Onyango, J.C.; Musyimi, D.M. Chlorophyll fluorescence, protein and chlorophyll content of three nerica rainfed rice varieties under varying irrigation regimes. J. Agric. Biol. Sci. 2010, 5, 19-25.

70. Rana, M.S.; Hasan, M.A.; Bahadur, M.M.; Islam, M.R. Physiological evaluation of wheat genotypes for tolerance to water deficit stress. Bangladesh Agron. J. 2017, 20, 37-52. [CrossRef]

71. Medrano, H.; Escalona, J.M.; Bota, J.; Gulias, J.; Flexas, J. Regulation of photosynthesis of $\mathrm{C}_{3}$ plants in response to progressive drought: Stomatal conductance as a reference parameter. Ann. Bot. 2002, 89, 895-905. [CrossRef]

72. Wright, H.; De Longa, J.; Ladab, R.; Prangea, R. The relationship between water status and chlorophyll a fluorescence in grapes (Vitis spp.). Postharvest Biol. Technol. 2009, 51, 193-199. [CrossRef]

73. Flexas, J.; Medrano, H. Energy dissipation in $C_{3}$ plants under drought. Funct. Plant Biol. 2002, 29, 1209-1215. [CrossRef]

74. Herzog, H. Source and Sink during Reproductive Period of Wheat; Scientific Publishers: Berlin/Hamburg, Germany, 1986; pp. 147-148.

75. Hosseinzadeh, S.R.; Amiri, H.; Ismaili, A. Evaluation of photosynthesis, physiological, and biochemical responses of chickpea (Cicer arietinum L. cv. Pirouz) under water deficit stress and use of vermicompost fertilizer. J. Integr. Agric. 2018, 17, $2426-2437$. [CrossRef]

76. Salehi, A.; Tasdighi, H.; Gholamhoseini, M. Evaluation of proline, chlorophyll, soluble sugar content and uptake of nutrients in the German chamomile (Matricaria chamomilla L.) under drought stress and organic fertilizer treatments. Asian Pac. J. Trop. Biomed. 2016, 6, 886-891. [CrossRef]

77. Navari-Izzo, F; Quartacci, M.F.; Izzo, R. Water stress induced changes in protein and free amino acids in field grown maize and sunflower. Plant. Physiol. Biochem. 1990, 28, 531-537.

78. Buttar, G.S.; Singh, C.J.; Ahuja, M.S.; Saini, K.S. Canopy temperature: A method to estimate plant water stress and scheduling irrigation in cotton and wheat. J. Agric. Physics. 2005, 5, 79-83.

79. Jackson, R.D.; Idso, S.B.; Reginato, R.J.; Pinter, P.J., Jr. Canopy temperature as a crop water stress indicator. Water Resour. Res. 1981, 17, 1133-1138. [CrossRef]

80. Maes, W.H.; Steppe, K. Estimating evapotranspiration and drought stress with ground-based thermal remote sensing in agriculture: A review. J. Exp. Bot. 2012, 63, 4671-4712. [CrossRef]

81. Lopes, M.S.; Reynolds, M.P. Partitioning of assimilates to deeper roots is associated with cooler canopies and increased yield under drought in wheat. Funct. Plant Biol. 2010, 37, 147-156. [CrossRef]

82. Blum, A.; Shipiler, L.; Golan, G.; Mayer, J. Yield stability and canopy temperature of wheat Osmotic adjustment and growth of barley genotypes under drought stress. Crop Sci. 1989, 29, 230-233. [CrossRef]

83. Gurumurthy, S.; Sarkar, B.; Vanaja, M.; Lakshmi, J.; Yadav, S.K.; Maheswari, M. Morpho-physiological and biochemical changes in black gram (Vigna mungo L. Hepper) genotypes under drought stress at flowering stage. Acta Physiol. Plant. 2019, 41, 42. [CrossRef]

84. Liang, X.; Zhang, L.; Natarajan, S.K.; Becker, D.F. Proline mechanisms of stress survival. Antioxid. Redox Signal. $2013,19,998-1011$. [CrossRef]

85. Mwadzingeni, L.; Shimelis, H.; Tesfay, S.; Tsilo, T.J. Screening of bread wheat genotypes for drought tolerance using phenotypic and proline analyses. Front. Plant Sci. 2016, 7, 1276. [CrossRef]

86. Delauney, A.J.; Verma, D.P.S. Proline biosynthesis and osmoregulation in plants. Plant J. 1993, 4, 215-223. [CrossRef]

87. Marcińska, I.; Czyczyło-Mysza, I.; Skrzypek, E.; Filek, M.; Grzesiak, S.; Grzesiak, M.T.; Janowiak, F.; Hura, T.; Dziurka Michałand Dziurka, K.; Nowakowska, A.; et al. Impact of osmotic stress on physiological and biochemical characteristics in droughtsusceptible and drought-resistant wheat genotypes. Acta Physiol. Planta 2013, 35, 451-461. [CrossRef]

88. Sultan, M.A.R.F.; Faisal, R.; Hui, L.; Yang, L.J.; Xian, Z.H. Assessment of Drought Tolerance of Some Triticum aestivum L. Species through Physiological Indices. Czech J. Genet. Plant Breed. 2012, 48, 178-184. [CrossRef]

89. Wasaya, A.; Manzoor, S.; Yasir, T.A.; Sarwar, N.; Mubeen, K.; Ismail, I.A.; Raza, A.; Rehman, A.; Hossain, A.; EL Sabagh, A. Evaluation of Fourteen Bread Wheat (Triticum aestivum L.) Genotypes by Observing Gas Exchange Parameters, Relative Water and Chlorophyll Content, and Yield Attributes under Drought Stress. Sustainability 2021, 13, 4799. [CrossRef]

90. Hasan, M.A.; Ahmed, J.U.; Bahadur, M.M.; Haque, M.M.; Sikder, S. Effect of late planting heat stress on membrane thermostability, proline content and heat susceptibility index of different wheat cultivars. J. Nat. Sci. Foun. Srilanka 2007, 35, 109-117. [CrossRef]

91. Budak, H.; Kantar, M.; Kurtoglu, K.Y. Drought tolerance in modern and wild wheat. Sci. World J. 2013, 2013, 548246. [CrossRef]

92. Saleem, M. Response of durum and bread wheat genotypes to drought stress: Biomass and yield components. Asian J. Plant Sci. 2003, 2, 290-293. [CrossRef]

93. Chaves, M.M.; Pereira, J.S.; Maroco, J.; Rodrigues, M.L.; Ricardo, C.P.; Osorio, M.L.; Carvalho, J.; Faria, T.; Pinheiro, C. How Plants Cope with Water Stress in the Field? Photosynthesis and Growth. Ann. Bot. 2002, 89, 907-916. [CrossRef] 
94. $\mathrm{Wu}, \mathrm{X}$; Bao, W. Influence of water deficit and genotype on photosynthetic activity, dry mass partitioning and grain yield changes of winter wheat. Afr. J. Agril. Res. 2011, 6, 5567-5574. [CrossRef]

95. Flexas, J.; Bota, J.; Loreto, F.; Cornic, G.; Sharkey, T.D. Diffusive and metabolic limitations to photosynthesis under drought and salinity in $C_{3}$ plants. Plant Biol. 2004, 6, 269-279. [CrossRef]

96. Tang, A.C.; Kawamitsa, Y.; Kanechi, M.; Boyer, J.S. Photosynthesis at low water potentials in leaf discs lacking epidermis. Ann. Bot. 2002, 89, 861-870. [CrossRef] [PubMed]

97. Serragoa, R.A.; Alzuetaa, I.; Savinb, R.; Slafer, G.A. Understanding grain yield responses to source-sink ratios during grain filling in wheat and barley under contrasting environments. Field Crop. Res. 2013, 150, 42-51. [CrossRef]

98. Maralian, F.; Ebadi, A.; Didar, T.R.; Haji-Eghrari, B. Influence of water stress on wheat grain yield and proline accumulation rate. Afr. J. Agril. Res. 2010, 5, 286-289. [CrossRef]

99. Li, Y.P.; Ye, W.; Wang, M.; Yan, X.D. Climate change and drought: A risk assessment of crop yield impacts. Clim. Res. 2009, 39, 31-46. [CrossRef]

100. Sallam, A.; Alqudah, A.M.; Mona, F.A.; Dawood, M.F.A.; Baenziger, P.S.; Andreas Börner, A. Drought Stress Tolerance in Wheat and Barley: Advances in Physiology, Breeding and Genetics Research. Int. J. Mol. Sci. 2019, 20, 3137. [CrossRef]

101. Youldash, K.M.; Barutcular, C.; EL Sabagh, A.; Toptas, I.; Kayaalp, G.T.; Hossain, A.; Alharby, H.; Bamagoos, A.; Saneoka, H.; Farooq, M. Evaluation of grain yield in fifty-eight spring bread wheat genotypes grown under heat stress. Pak. J. Bot. 2020, 52, 33-42. [CrossRef]

102. Farooq, M.O.; Kashif, M.; Khaliq, I.; Ahmed, N. Phenotypic Selection of Wheat Genotypes for Drought Stress Tolerance. Int. J. Agric. Biol. 2020, 23, 509-514. [CrossRef]

103. Farooq, S.; Shahid, M.; Khan, M.B.; Hussain, M.; Farooq, M. Improving the productivity of bread wheat by good management practices under terminal drought. J. Agron. Crop Sci. 2015, 201, 173-188. [CrossRef]

104. Qadir, S.A.; Khursheed, M.Q.; Huyop, F.Z. Drought tolerance and genetic diversity among selected wheat cultivars. Zanco J. Pure Appl. Sci. 2017, 29, 110-117. Available online: https://zancojournals.su.edu.krd/index.php/JPAS/article/view/893 (accessed on 6 September 2021).

105. Nazir, M.F.; Sarfraz, Z.; Mangi, N.; Nawaz Shah, M.K.; Mahmood, T.; Mahmood, T.; Iqbal, M.S.; Ishaq Asif Rehmani, M.; El-Sharnouby, M.; Shabaan, M.K.A.; et al. Post-Anthesis Mobilization of Stem Assimilates in Wheat under Induced Stress. Sustainability 2021, 13, 5940. [CrossRef]

106. Yasir, T.A.; Wasaya, A.; Hussain, M.; Ijaz, M.; Farooq, M.; Farooq, O.; Nawaz, A.; Hu, Y.G. Evaluation of physiological markers for assessing drought tolerance and yield potential in bread wheat. Physiol. Mol. Biol. Plants 2019, 25, 1163-1174. [CrossRef] [PubMed] 